(2) norden 



\section{Samspil mellem jordejere og friluftsliv}

Ida Kryger, Friluftsrådet

TemaNord 2007:592 


\section{Samspil mellem jordejere og friluftsliv}

TemaNord 2007:592

(C) Nordisk Ministerråd, København 2007

ISBN 978-92-893-1592-0

Tryk: Ekspressen Tryk \& Kopicenter

Oplag: 130

Trykt på miljøvenligt papir som opfylder kravene i den nordiske miljøsvanemærkeordning.

Publikationen kan bestilles på www.norden.org/order. Flere publikationer på

www.norden.org/publikationer

Printed in Denmark

Nordisk Ministerråd

Store Strandstræde 18

1255 København K

Telefon (+45) 33960200

Fax (+45) 33960202

\section{Nordisk Råd}

Store Strandstræde 18

1255 København K

Telefon (+45) 33960400

Fax (+45) 33111870

www.norden.org

\section{Det nordiske samarbejde}

Det nordiske samarbejde er en af verdens mest omfattende regionale samarbejdsformer. Samarbejdet omfatter Danmark, Finland, Island, Norge og Sverige, samt de selvstyrende områder Færøerne, Grønland og Åland.

Det nordiske samarbejde er både politisk, økonomisk og kulturelt forankret, og er en vigtig medspiller i det europæiske og internationale samarbejde. Det nordiske fællesskab arbejder for et stærkt Norden i et stærkt Europa.

Det nordiske samarbejde ønsker at styrke nordiske og regionale interesser og værdier i en global omverden. Fælles værdier landene imellem er med til at styrke Nordens position som en af verdens mest innovative og konkurrencedygtige regioner. 


\section{Indhold}

Et projekt om friluftsliv på privat jord......................................................................... 7

Sammenfatning - Projektets anbefalinger og konklusioner.............................................. 9

1. Allemandsretten - Retten til fri færdsel i naturen .................................................... 12

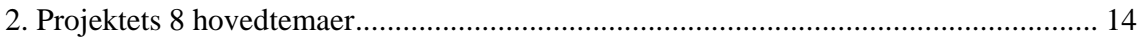

3. Retten til fri færdsel i naturen (Allemandsretten) anno 2007....................................... 16

4. Aktuelle tendenser indenfor friluftslivet og samspillet med jordejerne ........................ 19

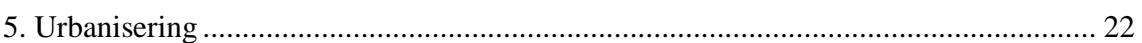

6. Lovgivning, frivillige aftaler og myndighedernes rolle .............................................. 25

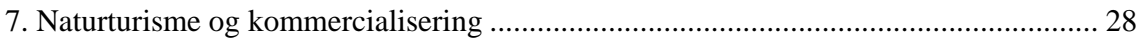

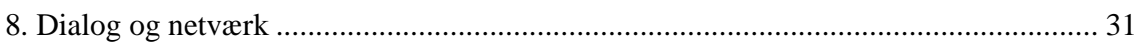

9. Dannelse og uddannelse - rettigheder og pligter ....................................................... 36

10. Forskning - Det nødvendige overblik over udviklingen............................................... 39

Konferenceindlæg 1

Friluftsliv på privat jord - Forudsättningar og visioner i Norden ..................................... 41

Konferenceindlæg 2

Sameksistens mellem jordejere og friluftsliv -

Input fra de fem nordiske lande forår 2007

Konferenceindlæg 3

Avtaler og forpliktelser mellom eiere og brukere i friluftslivet

Konferenceinlæg 4

At åbne sin ejendom for friluftslivet.

Konferenceindlæg 5

Den fælles nordiske ånd

Konferenceindlæg 6

Om stadsexpansion och friluftsliv i stadsranden............................................................. 53

Konferienceindlæg 7

Nature tourism - a growing sector in rural development......

Bilag 1

Deltagerlister

Bilag 2

Den nordiske konference Sameksistens mellem jordejere og friluftsliv 13. - 14. juni 2007, København. 



\section{Et projekt om friluftsliv på privat jord}

\section{Baggrund}

Nordisk Ministerråds styregruppe for miljøstrategi for jord- og skovbrug har bedt Friluftsrådet om at lave en mindre erfaringsindsamling vedrørende friluftsliv på private arealer i Norden.

Projektet, som blev gennemført i første halvår af 2007, skal bidrage til styregruppens arbejde med at foreslå prioriteringer indenfor nordisk arealplanlægning samt virke som indspil til de nordiske miljøhandlingsprogrammer for jord- og skovbrug i 2008.

\section{Formål}

Projektets formål er at samle de nordiske erfaringer og finde frem til de gode eksempler på friluftsliv på private arealer. Målet er at bruge den fælles nordiske viden til at skabe en god sameksistens mellem ejere og naturbrugere, samt foreslå nye initiativer til glæde for både friluftslivet og landbefolkningen.

Forskere, organisationsfolk, ejere, brugere og myndigheder har i dette projekt diskuteret udfordringerne og mulighederne i en tid, hvor sundhed og udeliv er i fokus.

Sammen har vi søgt at kikke i krystalkuglen og give nogle bud på udviklingen, samt fremhæve gode ideer og initiativer rundt omkring i Norden.

\section{Opbygning}

Projektet har fundet sted i perioden januar-juni 2007. I denne periode har der været et referencegruppe-møde i hvert af de nordiske lande samt en fælles nordisk 2-dags konference i København.

På de nationale møder deltog repræsentanter fra friluftslivet, ejerorganisationerne, myndighederne og forskningsverdenen. I alt deltog 55 personer i disse fem møder. I perioden frem til konferencen samlede projektkoordinatoren yderligere informationer fra de enkelte lande via indspil fra deltagerne. Alle deltagere på de nationale møder fik en invitation til den fælles nordiske konference.

Konferencen byggede ovenpå de konklusioner og indspil, som deltagerne fremsatte på de nationale møder. Forud for konferencen fik den bredt sammensatte gruppe af deltagere præsenteret de vigtigste udsagn fra 
de nationale møder. Via intenst workshopsarbejde på konferencen fandt deltagerne frem til de konklusioner, der gælder generelt i Norden. De fælles nordiske anbefalinger til Ministerrådet er blevet til på baggrund af dette arbejde.

Konferencen vekslede mellem dette workshopsarbejde og relevante indlæg.

\section{Deltagelse}

På hvert enkelt nationalt møde deltog en meget bredt sammensat gruppe på ca.12 personer. Nøje udvalgte engagerede personer medvirkede i hvert af de nordiske lande: de kom fra Ejerorganisationer, friluftsorganisationer, myndigheder og forskere.

De 25 konferencedeltagere udgjorde ligeledes en erfaren og bredt sammensat gruppe. Konferencen led dog under, at kun en enkelt deltog fra Finland, og at Island kun var repræsenteret kortvarigt.

\section{Rapportens indhold}

I nærværende rapport er de overordnede anbefalinger sammenfattet.

Efter en kort beskrivelse af Allemandsretten følger en gennemgang af otte relevante emner. Indenfor hvert emne er en samlet konklusion samt udtalelser og forslag fra både konferencen og de nationale møder. På den måde fremføres både de fælles nordiske men også de nationale input og kommentarer. Endvidere videregives gode eksempler fra de enkelte lande til inspiration

Anden halvdel af rapporten indeholder oplæggene fra konferencen, som bidrog til at skabe klarhed over den nyeste udvikling. 


\section{Sammenfatning \\ - Projektets anbefalinger og konklusioner}

Befolkningens adgang til friluftsliv bør have særlig høj prioritet hos beslutningstagerne, ikke mindst i lyset af de stigende sundhedsproblemer i alle de nordiske lande. Privatejede arealer byder på rige muligheder for udeliv, hvorfor samspillet med ejerne af produktionsarealerne er væsentligt.

Udviklingen indenfor samfundshelse, urbanisering, nye friluftsvaner og den mentale afstand mellem by og land har haft stor betydning for projektets konklusioner.

65 interessenter fra jord- og skovbruget, friluftsverdenen, forskningsinstitutionerne og myndighederne har via fem nationale møder og en fælles konference bidraget til følgende konklusioner:

Øget fokus og dialog

- Af hensyn til sundhed og livskvalitet bør alle borgere have let adgang til friluftsliv. En positiv sameksistens med jordejere er derfor af stor vigtighed, især ved de store byer, hvor færdslen på arealerne er størst. Det forventes, at presset på arealerne øges, og det anbefales, at beslutningstagerne og interessenterne skærper opmærksomheden og styrker dialogen, så mulige problemer ikke får lov at vokse sig store. Se eksempel på samarbejdsprojekt:Hestsam, Finland. Side 22

Byudvikling

- Let adgang for bybefolkningen til grønne, rekreative arealer skal sikres for at motivere til et sundt friluftsliv. Friluftsarealerne i og nær de store byer er under særligt pres fra bebyggelse og skal nyde ekstra bevågenhed og sikres kvalitativt og kvantitativt (jvf. Odense Deklarationen).

- Politikerne skal prioritere de rekreative arealer, når beboelsesområder udbygges. Der bør nedsættes særlige lokale fora med repræsentanter fra både ejer- og brugersiden for at sikre dialogen i planlægningsfasen. Se eksempel på bynær tilskudsordning: Rogaland, Norge. Side 26 


\section{Kommercialisering af friluftslivet}

- Helt overordnet bør adgangen til naturen være gratis.

- Det er myndighedernes ansvar, at den øgede kommercialisering af friluftslivet på private jorde ikke mindsker den almene befolknings adgang til et sundt udeliv.

- Kommercialisering skal ske på et bæredygtigt grundlag og have som formål at styrke udviklingen på landet til glæde for både brugere og ejere. Se eksempel på turistudviklingsprojekt: Fra Dal til fjell, Norge. Side 34

\section{Lovgivning og planlæegning}

- Naturbeskyttelseslovenes mulighed for arealbeskyttelse baseret på rekreative værdier (og ikke kun naturværdier) skal i højere grad udnyttes.

- Organisationerne skal sikres deltagelse i dialogen med private ejere via råd og nævn.

- Det skal sikres, at forvaltningerne gennemfører en helhedsorienteret planlægning for såvel de rekreative, de naturmæssige og de erhvervsmæssige interesser.

Dialog med forvaltningen: Se Grønne råd, Danmark. Side 29

\section{Uddannelse og almen dannelse}

- Der skal stimuleres til friluftsliv for børn og unge i skoleverdenen og i daginstitutioner, bl.a. via let adgang til naturen. Først og fremmest for at sikre sundheden, naturglæden samt de unikke nordiske traditioner for udeliv.

- Skoleværket bør pålægges et ansvar for, at viden om livet på landet samt kendskab til adgangsforhold og Allemandsrettens muligheder og forpligtelser integreres i undervisningen.

- Grundprincipperne i Allemandsretten skal endvidere spredes blandt nye nordboere.

- Fokus på udelivets positive effekter bør styrkes med en årlig fællesnordisk friluftsdag. Formidlingseksempel: En årlig allemansretsdag, Finland. Side 43

Forskning - overblik over udviklingen

- Der er behov for nye forskningsprojekter indenfor friluftsliv, helse, kommercialisering og sameksistens med de private jordejere.

- Vi foreslår et projekt, som skaber overblik over den forskning, der er udført indenfor friluftsliv og rekreation i Norden. Dette koblet til en webbaseret databank.

Se gruppens bud på vcesentlige fellesnordiske spørgsmål: Side 47 


\section{Nordisk netvcerk og dialog}

- Vi anser det for at være en opgave for Nordisk Ministerråd at støtte og tilvejebringe en platform for en fortsat dialog mellem de forskellige parter, som har bidraget til nærværende projekt. Endvidere bør der udvikles en internetbaseret nordisk friluftsportal.

- Konkret bør der arbejdes på et fælles nordisk friluftspolitisk program. 


\section{Allemandsretten - Retten til fri færdsel i naturen}

Et projekt der handler om samspillet mellem friluftsliv og jordejere i Norden, handler også om Allemandsretten. Her følger en kort beskrivelse af allemandsretten i de fem lande:

Norge

I Norge er allemandsretten lovfæstet. Allemandsretten gælder for ydermark. Dvs. ikke på dyrket mark eller helt tæt på beboelse. Dog må man færdes på dyrket mark, når denne er snedækket (15/10-30/4). Allemandsretten gælder for de der går, rider, cykler, løber på ski, sejler og bader. Den gælder ikke for motoriserede fartøjer. Man har lov til at overnatte mindst $150 \mathrm{~m}$ fra beboet hus og at samle bær, blomster, svampe og tørre grene. Man har ikke ret til at fiske og jage.

Læs mere på: www.aktivioslo.no/allemannsretten

\section{Sverige}

Allemandsretten i Sverige er ikke lovfæstet men en kulturelt betinget rettighed. Allemandsretten gælder for ydermark. Allemandsretten gælder ikke motoriseret trafik, men den gælder for de der går, rider, cykler, løber på ski, sejler og bader. Man har lov til at overnatte og at samle grene, bær, blomster og svampe. Allemandsretten giver ikke ret til at fiske og jage indlands. Større arrangementer kræver ejers samtykke.

Læs mere på: www.naturvardsverket.se/sv/Att-vara-ute-i-naturen

\section{Finland}

I Finland er allemandsretten ikke lovfæstet. Allemandsretten gælder ikke for motoriseret trafik, dog må man sejle med motorbåd på sejlruterne. Retten gælder for de der går, rider, cykler, løber på ski, sejler og bader. Man har lov til at overnatte og at samle grene, blomster, bær og svampe. Allemandsretten giver ret til begrænset fiskeri. 


\section{Island}

På Island er allemandsretten lovfæstet. Allemandsretten gælder for ydermark. Ejere kan dog hegne eller skilte og derved lukke områder af. Man kan gå, ride, cykle og løbe på ski, sejle og bade. Man må overnatte en enkelt nat med højst 3 telte (med mindre ejeren skilter mod det). Man må kun samle bær med ejerens tilladelse (dog frit til øjeblikkelig fortæring på græsgange i højlandet).

Læs mere på: $\underline{w w w . v i s i t i c e l a n d . c o m ~}$

\section{Danmark}

I Danmark bruges betegnelsen allemandsret ikke, men der findes dog regler for fri adgang til naturen, også den privatejede. Man må ikke færdes på landbrugsarealerne, som der er langt flere af i Danmark end i det øvrige Norden. Der er adgang til private skove, men kun på stier og veje. Man må ikke overnatte uden ejerens tilladelse. Man må samle de afbrækkede grene, bær, blomster og svampe, man kan nå fra vej og sti. Arrangementer for mere end 30 personer kræver tilladelse. Det skal nævnes, at i Danmarks offentlige skove er retten til færdsel mindre restriktiv.

Retten til at færdes på de danske strande er sikret ved lov. Det gælder til fods samt kortvarigt ophold og badning samt ridning i vinterhalvåret. Man må overnatte på strandene under åben himmel.

Læs mere på: www.skovognatur.dk/Ud/Adgang/Faerdsel 


\section{Projektets 8 hovedtemaer}

\section{Pointer, forslag og ideer fra projektet fordelt på 8 temaer}

På de nationale møder viste det sig hurtigt, at nogle særlige emner var i fokus i alle landene. Bl.a. urbanisering, retten til fri færdsel i naturen, samarbejdet med myndighederne og især arbejdet med at skabe dialog på personligt, lokalt og nationalt plan.

Deltagernes input på møderne blev samlet sammen, og mødernes udsagn blev bearbejdet på den fælles nordiske konference.

I rapportens første halvdel gennemgås projektets resultater fordelt på otte temaer. Disse temaer rummer alle projektets pointer samt gode eksempler og forslag.

Pointer, som fik generel tilslutning på den fælles konference er highlightet sidst i hvert kapitel som egentlige konklusioner. Det er disse fælles konklusioner, der ligger til grund for projektets anbefalinger.

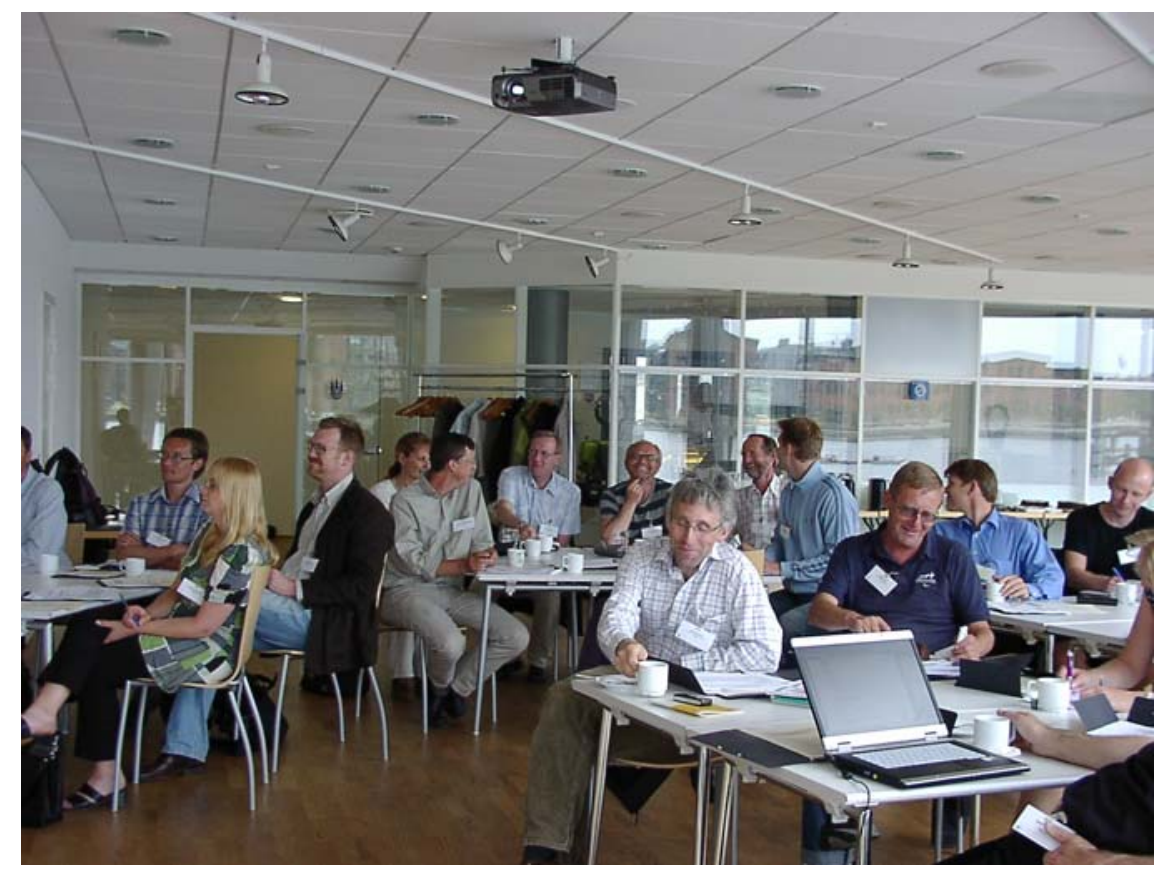


Temaerne er:

- Retten til fri færdsel i naturen (allemandsretten) anno 2007

- Aktuelle tendenser indenfor friluftslivet og samspillet med jordejerne

- Urbanisering

- Lovgivningen, myndighedernes og organisationernes rolle

- Naturturisme og kommercialisering

- Dialog og netværk

- Uddannelse og dannelse

- Relevante forskningsprojekter

Hvert tema gennemgås med en opsummering, nogle individuelle udtalelser, vigtige pointer fra møderne, gode nationale eksempler og endeligt de fælles nordiske konklusioner. 


\title{
3. Retten til fri færdsel i naturen (Allemandsretten) anno 2007
}

\begin{abstract}
Allemansrett er en sammensatt ting, og hvorvidt den lever i et lovverk, i hodene våre eller kroppene våre er et like sammensatt spørsmål.
\end{abstract}

Margrete Skår, Norsk Institutt for naturforskning (NINA)

Helt essentielt for det nordiske friluftsliv og natursyn er Allemandsretten. I projektet fastslås det, at den fri adgang til naturen er dybt forankret $\mathrm{i}$ vores fælles nordiske „friluftsånd“ og glæde ved naturen.

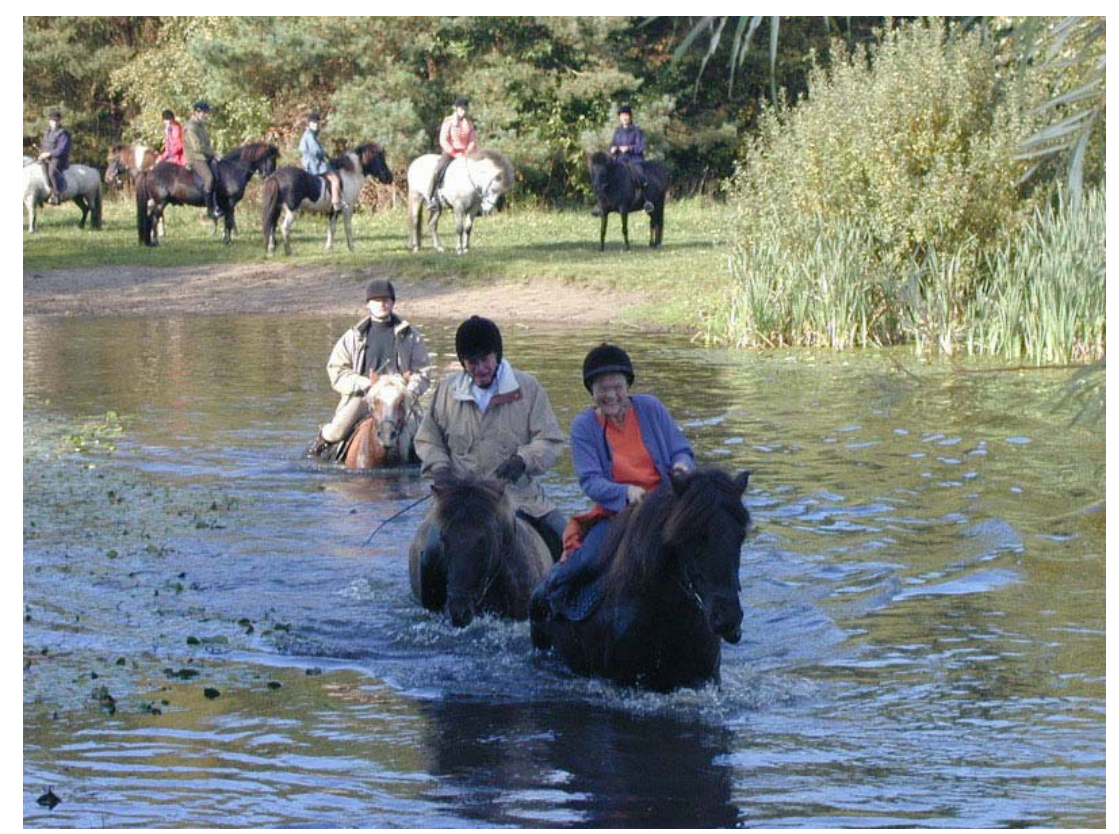

I Norge, Sverige, Finland og Island sikrer Allemandsretten den enkelte lov til at færdes på private arealer, overnatte og eventuelt indsamle til eget forbrug indenfor visse rammer. I Norge og på Island er retten lovfæstet. I Sverige og Finland er er der tale om en kulturelt udviklet rettighed.

Danmark afviger fra de andre nordiske lande ved et meget stort landbrugsareal, hvortil der ikke er adgang ud over veje og stier. Også reglerne for færdsel i private skove er mere restriktive end i de andre nordiske lande. Til gengæld er adgangen til de danske strande sikret med lov.

At retten til fri færdsel i naturen skulle forsvinde er utænkeligt for deltagerne, men strukturudvikling, kommercialisering af friluftsliv samt nye måder at bruge naturen på, kalder på årvågenhed og dialog om Allemandsretten. 
Risken finns framförallt när färre och färre får ett förhållande till vår natur och därmed inte förstår att allemansrätten är viktig.

Bo Sköld, Generalsekreterare i Friluftsfrämjandet, Sverige

De private grunneierne er også i mangt og meget avhangig av å kunne nytte en allemansrett straks de kommer utenfor egen eiendom. Allemansretten er også en utmerket anledning for jord- og skogbrukere til å bygge alianser med andre innbyggere. Gjennom et aktivt friluftsliv får øvrige deler av befolkningen et innsyn i de areelle næringer.

Vidar Holthe, Norges Skogeierforbund

Et vesentlig problem ift. Allemansretten i Norge er allemansrettens anledning til å starte kommersiell virksomhet på annen manns grunn med tillatelse gjennom allemansretten. F.eks utleie av hest eller organisert betalt ridning på annens eiendom. Dette burde betinge en avtale med grunneier, men i dag trenger man ikke dette. Vi har opplevd at veier har blitt så ødelagt at vi ikke har kunnet kjøre ut tømmer. Grunneier anla sak mot ridesenteret, men tapte i retten.

Gaute Nokleholm, Norskog, Norge

\section{Vigtige iagttagelser og udsagn, som vandt generel tilslutning på den fælles konference.}

For at bevare Allemandsretten er det vigtigt at styrke kontakten mellem jordejere og friluftsbrugere.

Blandt friluftsfolk er der en høj grad af selvjustits og man irettesætter gerne, hvis man oplever at Allemandsretten bliver misbrugt. Der er et stort ønske om at bevare retten til at færdes i naturen, hvorfor man stort set anvender den på rette vis.

Man oplever en øget tendens til skiltning mod adgang nogen steder.

En sammenligning i Norge, Finland, Island, Færøerne og Sverige mht. lovfæstet/ikke lovfæstet allemandsret kan fører til vigtig erfaringsudveksling til gavn for udviklingen.

Det er nødvendigt med uddannelse i, hvad retten til fri færdsel i naturen indebærer af muligheder og ansvar. Rettigheder og pligter i naturen skal være en del af skolernes curriculum.

\section{Konklusion}

- Det anbefales, at beslutningstagerne øger bevågenheden og sikrer, at den reelle allemandsret ikke indskrænkes. Nær de store byer er adgangen til kysten f.eks. truet af privat opkøb og hegning. De andre lande kan med fordel benytte de danske erfaringer med „allemansret“ i strandzonen. 
- Med flere og flere indbyggere i de nordiske lande kan Allemandsretten komme i konflikt med ejerne. Det er myndighedernes ansvar at være på forkant med udviklingen.

- Der bør laves planer for bevarelse af gamle stier og markveje, hvis forsvinden reelt er en indskrænkelse af adgangen.

- Der er i øvrigt brug for at udvikle og sprede viden om Allemandsretten, så også nye nordboere kan tage grundprincipperne til sig. 


\section{Aktuelle tendenser indenfor friluftslivet og samspillet med jordejerne}

Nye generationer er i ferd med å definere et mer varieret friluftsliv med anderledes innhold. Det er viktig å bidra til denne utviklingen.

Bjørn Helge Bjørnstad, Skogbrukets Kursinstitutt, Norge

På de nationale møder udtalte deltagerne sig om udviklingen indenfor friluftslivet generelt, samt den betydning udviklingen havde for sameksistensen med jordejerne. Mange tendenser viste sig at være ens i de nordiske lande, selvom der naturligvis er forskellige udfordringer fra land til land.

I samtlige nordiske lande oplever man en generel vilje til at undgå konflikter og finde løsninger for en god sameksistens mellem jordejere og friluftsfolk.

Men man oplever også et øget pres på grund af blandt andet urbanisering, øget behov for sunde fritidsaktiviteter, øget naturturisme og nye pladskrævende friluftsformer, der afløser traditionelt nordisk udeliv.

Nogle friluftsaktiviteter er særligt i fokus og kan give konflikter i fremtiden.

Skovbruget oplever klart en større efterspørgsel på aktiviteter. Ikke kun traditionelle aktiviteter, men i høj grad mere action-prægede aktiviteter.

Tanja Olsen, Dansk Skovforening

Vi bør vite mer om vi overhode har noen problemer. Jeg kjenner meg ofte ikke igjen i det jeg ser uttalt fra miljø- og friluftssiden i media i forhold til det jeg selv opplever. Verken som representant for grunneiersiden eller som friluftsutøver og aktiv deltaker i det lokale idrettsmiljøet.

Gaute Nokleholm, Norskog, Norge

En stigende del af dem, der bosætter sig på landet, har også lidt jord til. For nogen er det tilkøb af natur og „frakøb“ af, at andre kan bruge den natur. Det skaber grobund for konflikter.

Phillip Hansen, Landbrugsrådet, Danmark

Hest som en del av allemansretten har ført til noen problemer. Veier tråkkes i filler, slik at tømmer kan ikke transporteres, tråkk på rothalser i skog øker råtefaren vesentlig, og vi har dessuten opplevd nestenulykker ved møte mellom hest og tømmerbiler vinterstid. 


\section{Ideer og gode eksempler}

\section{HESTsam, Finland}

Finansieres af Jord- og skovbrugsministeriet og har til formål at finde gode eksempler på sameksistens mellem jordejere og rideklubber på kommuneplan. Et eksempel kunne være fælles ruteplanlægning.

Levende Skov, Norge

Er støtte til at udvikle skoven ud fra andre kriterier end størst muligy afkast.

\section{Spor i Landskabet, Danmark}

En kampagne, der støtter landmændene i at etablere stier og spor ad frivillighedens vej (www.spor.dk).

\section{Mezoprogrammet i Finland}

giver økonomisk støtte til udvikling af skov ud fra to temaer: Biodiversitet og rekreativ værdi.

\section{Bondelaget i Norge}

har udgivet materialet „Gode oplevelser i kulturlandskabet, Norges Bondelag “ til medlemmerne vedrørende samspillet med friluftslivet og hvordan de kan skabe en win-win situation på deres arealer. Uddrag følger:

\footnotetext{
„Veksten i byer og tettsteder, mer fritid og behov for friluftsområder i nærområder, øker etterspørselen etter fysisk tilrettelegging i kulturlandskapet. Det kan være tilrettelagte sykkeltraseer, rideveier eller turveier for ferdsel til fots. Hva kan du som bonde gjøre for å ta i bruk kulturlandskapet mer aktivt i næringssammenheng? Hvordan bør du forholde deg til andre som bruker kulturlandskapet som opplevelsesarena? Kan man gjennom aktiv tilrettelegging skape gode relasjoner mellom landbruket og allmennheten?“
}

www.bondelaget.no/tema/pdf/Bondelaget_kulturlandsk_klar-til-trykk.pdf

\section{Vigtige iagttagelser og udsagn, som vandt generel tilslutning på den fælles konference.}

Friluftsliv er essentiel for at skabe forståelse for naturbevarelse.

Jordejerne har krav på respekt omkring den virksomhed, de driver.

Hvor vi tidligere har oplevet en vandring fra land til by, ser vi nu, at byboer flytter på landet for at få roen og naturen tilbage. De nye fritidslandmænd kan have et stærkt ønske om ikke at dele deres nyvundne naturområder med andre.

Nogle steder er der en tendens til en angloamerikansk „ingen gennemgang“ ideologi. Så ser vi flere hegn og skilte med „privat“. 
Motoriserede aktiviteter, f.eks. snescootere, vandscootere og 4-hjuls trækkere,er et stigende problem i nogle lande. Man oplever øget kørsel i skovene udenfor vejene til gene for naturen, ejerne og de øvrige brugere.

En nyere aktivitet, som giver problemer og diskussion i nogle nordiske lande, er mountainbikes.

Kanosejlads er også en af de mere belastende friluftsaktiviteter i nogle lande. Jordejeren oplever af og til en krænkelse ved netop denne aktivitet.

Klimaforandringerne vil måske medføre store forandringer indenfor friluftsliv og naturturisme.

\section{Konklusion}

- Af hensyn til sundhed og livskvalitet bør alle borgere have let adgang til friluftsliv. En god og positiv sameksistens med jordejere er derfor af stor vigtighed, især nær de store byer, hvor presset er størst.

- Blandt andet i lyset af et øget pres på arealerne anbefales det, at beslutningstagerne og interessenterne øger opmærksomheden og styrker dialogen, så eventuelle problemer ikke får lov at vokse sig store.

- Det er nødvendigt at definere om nyere og kommende friluftsformer kræver speciel planlægning og tilrettelæggelse for at tilgodese naturværdier og undgå konflikter mellem brugergrupperne. 


\section{Urbanisering}

Idag så ser vi att trycket på de markägare som finns tätortsnära har ökat kraftigt. Orsaken till det är flera, kunskapsbristen är en. Men antalet markägare som brukar jorden aktivit har minskat samtidigt som många i de tätortsnära områdena bedriver friluftsliv, vilket gör att de få aktiva markägarna känner av trycket från friluftslivet hårdare.

Eilert Apelqvist, Lantbrukarnas Riksförb, Sverige

Alle er enige om, at det er af største vigtighed at sikre let adgang til grønne, rekreative arealer for bybefolkningen for at motivere til et sundt friluftsliv.

De fleste nordboere bor idag i de store byer, og det er naturligt at se på det rekreative liv i og nær storbyerne med særskilt fokus. Mulighederne på private arealer nær byerne kan og skal udnyttes.

Friluftsarealerne i og nær de store byer er under særligt pres og skal nyde ekstra bevågenhed og sikres kvalitativt og kvantitativt.

For jordejernes vedkommende er der særlige udfordringer nær byerne pga. et stort antal brugere. Iblandt trues de også af byudviklingen og de kommercielle interesser. De bynære jordejere bør i særlig grad inddrages i dialog og nyde en særlig tillid og forståelse. Særlige fora som f.eks. Grønne Råd skal sikre dialogen med private jordejere nær byerne.

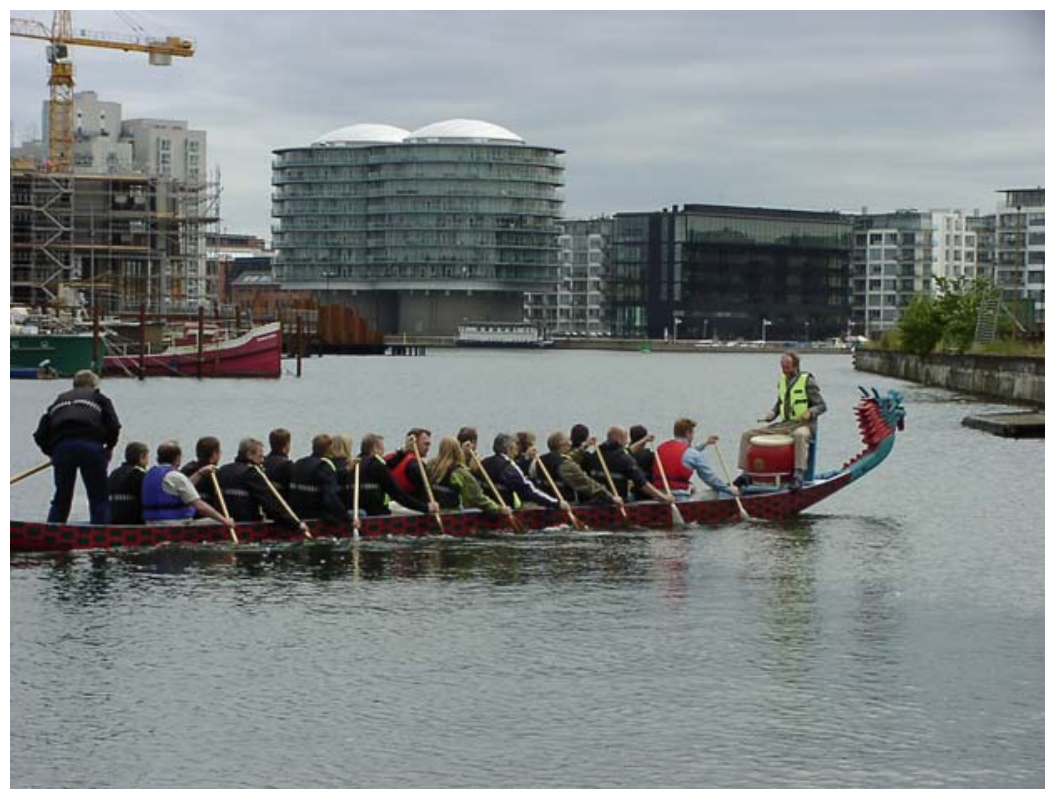


Nära tätorter är det motiverat att prioritera rekreation och friluftsliv före traditionell virkesproduktion. Särskilt viktigt är det att stimulera barn och ungdomar att uppleva skog och natur.

Bo Skjöld, Friluftsfrämjandet, Sverige

„Udfordringer i nærområder til store befolkningsområder blir blåst opp til generelle problemer for hele landet uten rimelig grunn. Dette kan svekke samarbeidsviljen hos grunneierne også i distriktene. Det er viktig at landsdekkende frilufts- og miljøorganisationer er dette ansvaret bevisst. De må holde seg i takt med situasjonen i landet set under et og ikke agerer som om alle steder i Norge er som Oslomarka.“

Gaute Nokleholm, Norskog, Norge

\section{Ideer og eksempler}

\section{Erfaringerne fra Oslomarka}

Her arbejder et større antal kommuner sammen om at planlægge for et større naturareal i fællesskab.

\section{Det Grönne Skarfet}

Er et stort udflugtsområde med skov og søer omkring Reykjavik. Planlægning og udvikling sker i et samarbejde mellem kommunerne og skovforeningen. Udfordringen for dette forum er at finde frem til, hvordan Det Grönne Skarfet skal fungere I sin helhed.

\section{Tilskud til Rogalands bønder}

I Rogaland findes en tilskudsordning, så at bønder, der åbner deres ejendom for vandrere, kan få et årligt tilskud på $8 \mathrm{Nkr}$ pr meter sti. Kravet er, at bonden sørger for at stien er holdt og godt afmærket, samt at der er parkeringmuligheder i nærheden.

Litt av bakgrunnen for at vi har valgt å gi tilskudd til turstier i landbruksområder, er at det er stort press på utbygging av jordbruksareal i deler av fylket vårt. Ved å åpne opp jordbruksareal/kulturlandskap for turgåere håper vi at flere brukergrupper ser verdien av å ta vare på jordbruksareal. Flerbruk av arealer kan være med å redusere utbyggingspress/utbyggingstakt på noe av de mest Ordningen har blitt veldig godt mottatt av bøndene. I 2006 ble det søkt om tilskudd til ca $460 \mathrm{~km}$ slike turstier i Rogaland. 


\section{Vigtige iagttagelser og udsagn, som vandt generel tilslutning på den fælles konference.}

Der vil i de kommende år blive brug for flere friluftsarealer, så belastningen bliver mindre på det enkelte område. De rekreative arealer skal tænkes ind i planlægningsprocesserne fra starten, når beboelsesområder udbygges.

For nogle lande gælder det, at der er stor forskel fra nord til syd. Tag hensyn til, når problemerne er mindre aktuelle i de områder, hvor der er mindre arealkonkurrence.

Ridning er en aktivitet, der udvikler sig meget nær de store byer. Det er vigtigt, at udvikle nye rideruter i fællesskab, inden presset bliver for stort.

Byudviklingen udgør en vis trussel for naturområderne. Den traditionelle planlægning i henhold til planlægningsloven er ikke stærk nok.

Vi oplever stadig oftere, at skovområder og bygningsaktivitet havner $\mathrm{i}$ konflikt.

\section{Konklusion}

- Politikerne skal prioritere midler til de rekreative arealer i planlægningsprocesserne, når beboelsesområder udbygges.

- Det anbefales, at der tages vare på spontan opstået natur, frigivede arealer og andre friarealer i byerne, som kan finde rekreativ anvendelse.

- Enhver by må have en formel, lovfæstet afgrænsning mod landarealerne.

- Der bør arbejdes på en større opfindsomhed hvad angår sameksistens mellem det urbane miljø, bebyggelse og friluftsliv. 


\section{Lovgivning, frivillige aftaler og myndighedernes rolle}

Friluftslivets intressen ska väga lika tungt i samhällsplaneringen som andra intressen, som bostadsbyggande, kommunikationer, tävlingsidrott etc.

Bo Skjôld, Friluftsfrämjandet, Sverige

Når talen falder på friluftsliv på private jorde, er det klart at det formelle spiller en vigtig rolle. Er der lovgivning, der understøtter aktiviteter og samspil? Kan frivillige aftaler forbedre samarbejdet og sikre parternes retsfølelse? Hvordan agerer de lokale og nationale myndigheder? På møderne var både ejere og brugere enige om, at myndighederne spiller en vigtig rolle for arealplanlægning, friluftsmuligheder og hensynet til ejerne.

På alle møderne blev det fremhævet, hvor vigtig dialogen mellem myndighederne og organisationerne er. Med inspiration fra Grønne Råd i Danmark anbefales det, at der i alle lande skabes lokale fora, hvor organisationer og erhverv kan mødes og samarbejde.

Hvad lovgivning angår, pegede flere på de uudnyttede muligheder for beskyttelse, der ligger i Naturbeskyttelseslovene. Her er der oftest mulighed for beskyttelse og management baseret på rekreative interesser, disse udnyttes bare ikke.

I det hele taget ligger det deltagerne meget på sinde, at forvaltningerne gennemfører en helhedsorienteret planlægning for såvel de rekreative, naturmæssige og erhvervsmæssige arealer og interesser.

Der skal fokus på landskabsplejeplaner, således at disse udvides til også at omfatte rekreative aspekter.

En god idé med klare samarbejdsaftaler med kommune om service og rekreativt samarbejde.

Ole Hjort Caspersen, Københavns Universitet, Danmark

Skovforeningen kunne ønske sig et større samarbejde mellem private skove og kommuner og/eller foreninger. Vi finder lovgivningen som sådan er dækkende, men at det er vigtigt at bevare dialogen også på det politiske plan, så der sker tilpasninger i takt med den almene udvikling i samfundet.

Tanja Olsen, Dansk Skovforening

De gode eksempler har vi fler af. Det er utabudet aftaler for forskellige aktiviteter hvor grunneiersiden og allmennheden er aftalepartnere. Det gælder for ridning orientring mm. Se www.skog.no/html/Utmark/kontrakt.asp under friluftslivsaktiviter 
Lagstiftningen i Sverige (Miljöbalken, 16 kap. 13 §) ger miljöorganisationer möjlighet att överklaga vissa beslut om tillstånd, godkännande och dispens. Denna rätt gäller endast miljöorganisationer. Vi önskar att denna rätt att överklaga även omfattar friluftsorganisationer.

Ulf Silvander, Svenskt Friluftsliv

Dialog er vigtig. Lokale aftaler virker og er smidigere end lovgivning.

Johan Scheel, Godsejer, Danmark

I tillegg har nasjonale friluftslivsorganisasjoner og grunneierorganisasjoner blitt enige om standardavtale for tilrettelegging og merking av turstier og turskiløyper, som kan legges til grunn når lokale lag og organisasjoner skal inngå avtaler:

Morten Dåsnes, Friluftsrådenes landsforbund, Norge

\section{Ideer og eksempler}

\section{Kan kommunerne facilitere jordejerne bedre?}

Det er ønskeligt med en offentlig instans, der faciliterer de jordejere, der gerne vil åbne mere op. Vi ønsker samme vilkår i alle distrikter og en viden om, hvor man skal henvende sig for at få hjælp til affaldsspande, P-plads etc.

\section{Besøg af Friluftsforum, Finland}

Et friluftsprojekt rettet mod kommuner i 2008-2010 i Finland. Alle kommuner får besøg af „Friluftsforum“, og i den forbindelse diskuteres kommunens friluftsfaciliteter. Aktiviteten gennemføres af Suomen Latu og Friluftsforum.

\section{Grønne Råd og Lokalråd, Danmark}

Sikrer dialog, hvor organisationerne også bliver hørt.

\section{Aftalerne i Norge}

Der gøres et stort arbejde mellem ejer- og friluftsorganisationerne for at udfærdige fortrykte aftalepapirer. Standardaftaler for tilrettelæggelse og anlægning af turstier og skiløjper

\section{Norske Skærgårdsparker}

Eksempler på avtalebaserte ordninger for å sikre friluftsinteresser er norske Skjærgårdsparker bygd på servituttavtaler. En servituttavtale innebærer at områdene stilles til varig rådighet som friluftsområde for allmennheten. Grunneierne beholder eiendomsretten og rett til å bruke områdene på tradisjonelt vis som $\mathrm{f}$. eks. beiting og høsting. Samtidig er det ikke anledning for grunneier å gjøre naturinngrep som forringer kvaliteten av området eller hindrer bruken til friluftsformål. Deltakelse i Skjærgårdsparken er frivillig (se Harvold K. et al. 2006). 


\section{Vigtige iagttagelser og udsagn, som vandt generel tilslutning på den fælles konference.}

Vi har brug for at få beskyttet rekreative og naturrige områder, strande, korridorer, stier etc. Lovene er der, men bliver ikke brugt tilstrækkeligt.

Det er et generelt problem, at distrikterne ikke administrerer lovgivningen ens.

Organisationer har mere eller mindre mulighed for at influere på planloven i de forskellige lande. Det er vigtigt, at organisationerne tager deres ansvar alvorligt og hele tiden uddanner sig.

Lovgivningen skal give plads til rationel opførsel. Loven skal ikke blive for striks.

Man kan sætte spørgsmålstegn ved, om lovgivningen er tidssvarende og tilstrækkelig til at beskytte landzonerne og friluftslivet.

\section{Konklusion}

- Med inspiration fra Grønne Råd i Danmark anbefales det, at der i alle lande skabes lokale fora, hvor organisationer og erhverv kan mødes og samarbejde.

- Organisationerne bør have udvidet klageret for at sikre en dialog med de involverede parter og sikre en god planlægning.

- Endvidere anbefales det, at Naturbeskyttelseslovens mulighed for beskyttelse og management baseret på rekreative interesser udnyttes i højere grad end i dag.

- Det ligger deltagerne på sinde, at forvaltningerne gennemfører en helhedsorienteret planlægning for såvel de rekreative, de naturmæssige og de erhvervsmæssige arealer og interesser.

- De nordiske lande bør styrke en fælles nordisk friluftspolitik. 


\title{
7. Naturturisme og kommercialisering
}

\begin{abstract}
Den stor udfordring fremadrettet er visses ønsker om at kapitalisere naturoplevelserne. Det vil udelukke nogle grupper, men omvendt kan det være med til at styre brugen og bl.a. forhindre interessekonflikter i mellem forskellige brugergrupper.
\end{abstract}

Phillip Hansen, Landbrugsrådet, Danmark

Med en øget oplevelsesøkonomi øges mulighederne for at tjene penge på at organisere friluftsaktiviteter. De positive effekter er innovativ naturturisme og øget service til brugerne samt flere entreprenøropgaver og indtægtsmuligheder for jordejerne. Faren er begrænsninger og overbelastning af naturen. I de enkelte lande er man bekymret for, om udviklingen kommer til at foregå tilfældig uden sikker styring af de økonomiske interesser.

Der er ingen tvivl om, at naturen er blevet en salgsvare. Lovgivningen bør udvikles løbende, og vi har brug for en afklaring vedrørende det stigende pres på brugen af økonomi som styringsredskab.

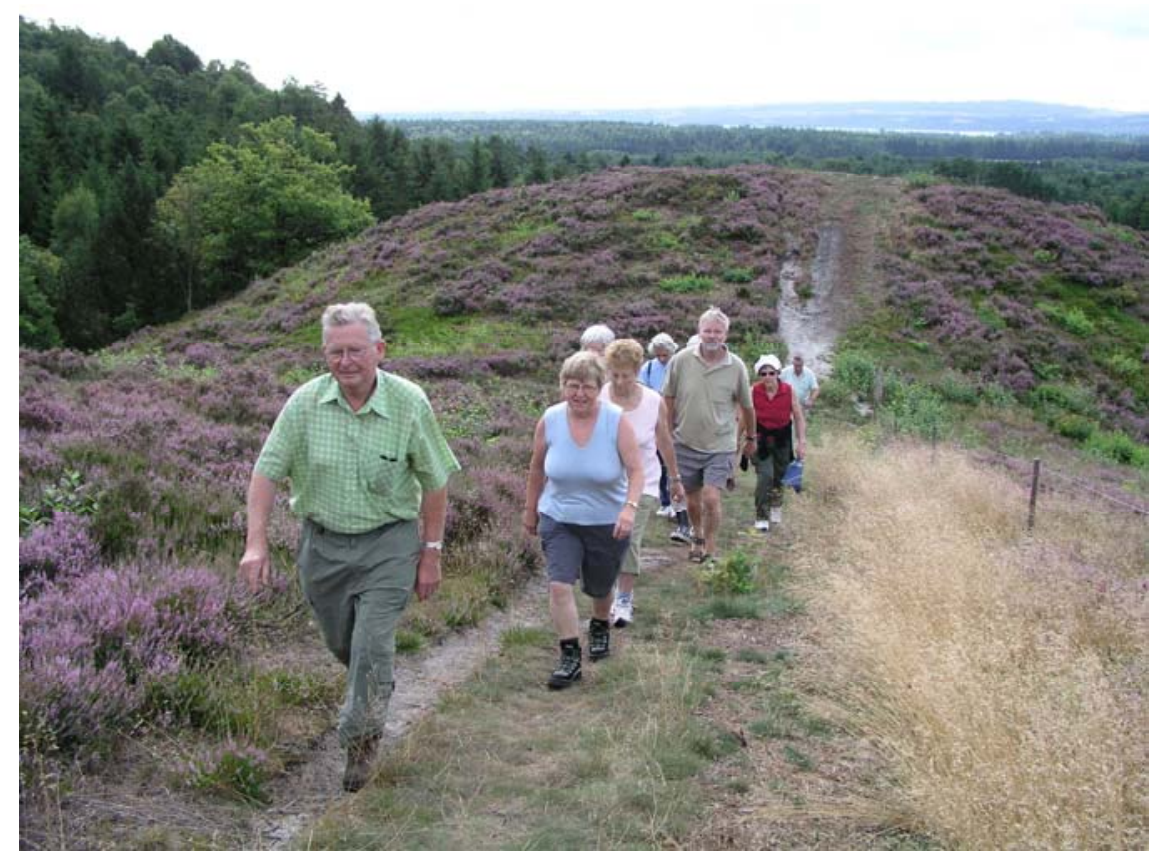


För att naturturism skall kunna bedrivas utan konflikter är det nödvändigt att den är lokalt förankrad och markäagrperspektivet beaktas så att verksamheten bl.a bedrivs genom avtal.

Eilert Apelqvist, Lantbrukarnas Riksförb, Sverige

\section{Ideer og eksempler}

\section{Recreational Value Trading Concept, Finland}

MTK i Finland arbejder på et initiativ: „Recreational Value Trading Concept“. Landejerne kompenseres for at gennemføre „blødt“ skovbrug. Det kan være en måde at få skovene beskyttet til rekreation og bevarelse.

\section{Erfaringer fra Rogerland. Norge}

Her betales grundejere $8 \mathrm{Nkr}$ pr meter for at anlægge turstier i inmark (hvor Allemandsretten ikke gælder). De skal mærkes på kort, og der skal anlægges p-plads. Her betales for en rettighed, som ikke allerede findes i friluftsloven.

\section{Landsbyprogrammet, Sverige}

De nye støttemuligheder fra EU-puljer giver gode muligheder for friluftsliv. Der gives støtte til f.eks bevaring. Det kan være en organisation, der står for det. Der skabes nye muligheder. Men det er samtidig en udfordring for Allemandsretten, da man pludseligt begynder at betale for noget, som tidligere var en selvfølgelig ret.

\section{Primitiv Overnatning, Danmark}

Et netværk af meget billige primitive overnatningspladser stillet til rådighed på både offentlig og privat jord (www.teltpladser.dk).

\section{Fra Dal til fjell, Norge}

Et enestående samarbejde mellem Bondelaget og Turistorganisationen. Fokus på økonomien på landet. Der arbejdes på at skabe sammenhæng mellem naturturisme og landbefolkningen, for at skabe nye næringsveje på landet på en ordentlig og hensigtsmæssig måde.

\section{Hceftet „Godde oplevelser i kulturlandskabet“, Norge}

Uddrag af hæftet, som giver råd om næringsvirksomhed og almen færdsel:

I brosjyren kan du blant annet lese om hvordan du fysisk kan tilrettelegge for ferdsel i kulturlandskapet, hvilke regler som gjelder i følge friluftsloven og hvordan kulturlandskapet kan brukes som innsatsfaktor i utviklingen av et reiselivsprodukt.

Gyllen omvei på Inderøy: Den Gyldne Omvei er en veistrekning gjennom Inderøy kommune i Nord-Trøndelag, der et andelslag av 19 småbedrifter har ulike tilbud knyttet til gårdsutsalg, matservering, kunst og kultur, opplevelser og over- 
natting. Kulturlandskapet danner en viktig ramme rundt de enkelte bedriftene, og blir også brukt aktivt i markedsføring.

www.bondelaget.no/tema/pdf/Bondelaget_kulturlandsk_klar-til-trykk.pdf

\section{Vigtige iagttagelser og udsagn, som vandt generel tilslutning på den fælles konference.}

Der vil gradvist ske en øget kommercialisering. Oplevelsesøkonomien vokser, f.eks. ved jagt og fiskeri.

Kapital får mere betydning og vil muligvis lukke af og mindske adgangen til naturen for nogle grupper.

Større hytter, organiseret friluftsliv og nye former afløser den gamle friluftstradition. Det stiller større og nye krav til både lovgivningen, aftaleværktøjer og dialog. Der bliver måske også brug for nye redskaber, f.eks. visse former for betaling.

Friluftsturismen udfordrer Allemandsretten. Nogen tjener penge på Allemandsretten på bekostning af de der ejer jorden.

Fremtiden byder på mere friluftsliv i grupper.

Sameksistens mellem jordbrug og friluftsliv har et stort udviklingspotentiale. Der er fælles interesse for de som arrangerer og udfører friluftsliv og landejerne.

Der er vigtigt, at de nationale tilskud og EU tilskud, som landene modtager og anvender til forvaltningen i det åbne land, anvendes til forbedringer af naturindholdet $i$ landskabet.

Politikerne skal i højere grad tage ansvar for at trække grænsen mellem Allemandsret og kommercielt friluftsliv. Det er nødvendigt med en tydelig definition på Allemandsretten.

\section{Konklusioner}

- Helt overordnet bør adgangen til naturen være gratis.

- Myndighederne bør påtage sig et ansvar for, at den øgede kommercialisering af friluftslivet på private jorde ikke mindsker visse gruppers adgang til et sundt udeliv. Kommercialiseringen skal ske på et bæredygtigt grundlag og have som formål at styrke udviklingen på landet til glæde for både brugere og ejere.

- Særlig opmærksomhed kræves hvor nogen tjener penge på Allemandsretten på bekostning af de, der ejer jorden. 


\section{Dialog og netværk}

Det er vigtigt at få frem lighederne i det nordiske friluftsliv. Stolthed og bevidsthed om den fæles nordiske kultur skal formidles ad mange veje.

Arbejdsgruppe på konferencen

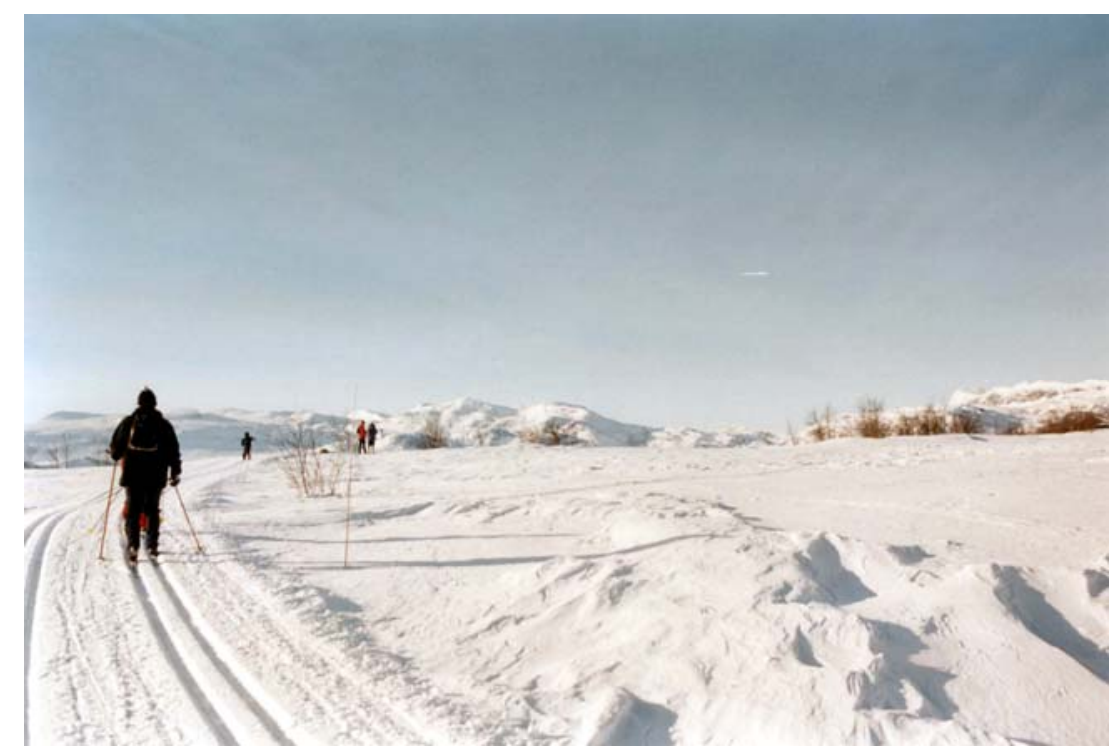

Møderne mellem de forskellige interessenter i nærværende projekt blev af alle opfattet som meget givende, og værdien af dialogen blev af alle trukket frem som et særligt potentiale, der bør arbejdes videre med i nordisk regi.

På det mere hverdagspraktiske plan skal dialogen mellem enkeltpersoner ude i felten, mellem lokale grupper, mellem myndigheder og organisationer og mellem ejer- og friluftsorganisationer bør opprioriteres fremover.

Kommunikation på alle niveauer skal sikre, at færdslen i naturen udvikles på en hensigtsmæssig måde uden store konflikter.

Èn deltager fremhævde gevinsten ved dialog på et tidligt stadie i planlægning af f.eks rideruter.

Om at skabe arenaer for dialog: Det er nødvendigt med nye fora, som faciliterer dialogen mellem forskellige brugere, for at undgå konflikter i en fremtid med større pres på arealerne.

Som nævnt var der fokus på projektets egen dialogfremmende funktion, og der var et stort ønske om, at Ministerrådet tilvejebringer en platform, der kan videreføre denne dialog mellem landene og mellem interessenterne, f.eks via en internetbasseret portal og et årligt møde. 
Endvidere var der ideer fremme om en internetbaseret portal for friluftsfolk, forskere og administration. Siden skal være en serviceside og en databank om friluftsmuligheder, rettigheder og ansvar i de forskellige nordiske lande. Den skal også formidle forskningsresultater og udviklingsprojekter.

Det må blive mere vanligt med faste kontaktpunkter og at gruneirsiden inviteres til semina, konferencer mm hvor spørgsmål som berører dem tages op.

Arild Sørensen, Direktoratet for naturforvaltning, Trondheim, Norge

Då kommunerna i Sverige har planmonopol (dvs. Det är kommunerna som bestämmer var och hur marken i kommunen skall användas) önskar vi att kommunerna bjuder in friluftsorganisationerna (och andra organisationer) för att diskutera och förankra sina förslag.

Ulf Silvander, Svenskt friluftsliv

\section{Ideer og eksempler}

\section{Forskningsnetvcrk}

Vi kunne ønske et netværk mellem nordiske forskere og praktikere, som arbejder med rekreative aspekter nær byområder i Norden.

Det finske input kunne f.eks være forskningsprogrammet „Welfare Impacts of Forrest“ af Finish Forest Institute.

\section{Eksempel fra ridesporten (Finland):}

Dialogen sker på flere planer. På lokalt niveau mellem ryttere og jordejere, på bilateralt niveau mellem landejerne og rideklubber og på nationalt niveau mellem landbrugsorganisationer og rideforbund. Der er endda en dialog mellem beslutningstagere og samtlige hesteorganisationer.

\section{Samarbejdsudvalg, Norge}

I Norge findes der eksempler på samarbejdsudvalg for friluftsliv på kommuneniveau.

\section{Samarbejdsaftale vedrørende gåruter, Finland}

MTK og SLC (Finske jordejerforbund) har lavet en aftale med Suomen Latu (friluftsorganisation) og kommunerne vedrørende gåruter i 2002. Disse genforhandles i 2008.

\section{Mødeforum, Finland}

Finske Ulkoilenfoorumi (Voluntary Outdoor Forum) er et eksempel på et forum, hvor parterne mødes og diskuterer temaer indenfor Allemandsretten. Ejerorganisationer og ministeriet er også med her. 


\section{Friluftsråd som paraply}

I Danmark oplever vi det som en god idé med et Friluftsråd som samler baglandet i høringssvar etc.

\section{Grønne Råd, Danmark}

Grønne Råd i de danske kommuner samler interessenter i natur- og friluftsspørgsmål.

\section{Oslomarken, Norge}

Arbejdet med Oslomarken som rekreativt område er et eksempel på nødvendigt samarbejde mellem mange kommuner

\section{Levende skog i Norge}

Levende skog er samarbeidet mellom skogeierorganisasjonene og miljøorganisasjonene som er grunnlaget for PEFC sertifiseringen av skogbruket i Norge. www.skog.no/skog_data/Attachments/497/Revidert.Levende.Skog.pdf

Bjørn Helge Bjørnstad, Skogbrukets Kursinstitutt, Norge

\section{Samarbejdsaftaler i Norge}

Det fins i Norge flere eksempler på samarbeidsavtaler mellom friluftslivsorganisasjoner og grunneierorganisasjoner. Ett eksempel er Norges orienteringsforbund som har: „Avtale om retningslinjer for o-idrettens forhold til naturmiljø og rettighetshavere“ (www.orientering.no)

Morten Dåsnes, Friluftsrådenes Landsforbund, Norge

\section{Sektorsråd i Sverige}

Skogsstyrelsen har organiserat nationella, regionala och lokala sektorsråd. Råden består av representanter från skogliga aktörer, bioenergiproducenter, högskolor, universitet, ideella organisationer, allmänheten, m.fl.

Syftet med råden är att det skall finnas en möjlighet för skogsbranschen, organisationer och allmänheten att föra en dialog med Skogsstyrelsen samt att få en inblick i det arbete som Skogsstyrelsen gör. Råden träffas ett par gånger per år och då diskuteras olika problem och frågeställningar. En mycket viktigt bit är som sagt var arbetet med att utforma och genomföra arbetet med sektorsmålen på olika nivå inom respektive organisation.

Sektorsmålen utgör en uttolkning av den statliga skogs- och miljöpolitiken. I sektorsmålen formuleras bland annat hur sektor ska arbete med skogens sociala värden. 
Fra Dall til Fjell, Norge

Samarbejde mellem jordejerorganisationer og turistorganisationen.

Herunder ses to uddrag af hæftet:

Turene vi presenterer i programmet „Fra dal til fjell“ er resultat av et nytt samarbeid mellom Den Norske Turistforening, Norges Bondelag, Kulturgardar i Gudbrandsdalen og Innovasjon Norge. „Fra dal til fjell“ være et viktig pilotprosjekt for å synliggjøre viktigheten av samarbeid mellom by og land - mellom friluftsliv og landbruk.

Kommunen søkte og fikk fylkeskommunale midler til å legge til rette for ferdsel langs strandlinja. Grunneierne reagerte på at de ikke ble involvert i planene og krevde å overta styringen av prosjektet dersom det skulle gjennomføres. Kravet ble positivt mottatt av kommunen og det lokale historielaget,og man satte sammen en gruppe der alle parter var representert.

Resultatet ble et bedret friluftstilbud for folk i kommunen, og en løsning som grunneierne er fornøyd med. Langs stien er det lagt til rette med bålplasser og informasjonstavler om områdets natur- og kulturverdier.

www.bondelaget.no/tema/pdf/Bondelaget_kulturlandsk_klar-til-trykk.pdf

\section{Vigtige iagttagelser og udsagn, som vandt generel tilslutning på den fælles konference.}

Vi skal tage ved lære af hinanden i Norden: Lad os høre, hvad der findes af formelle kontaktforaer mellem ejere og brugere. Hvad gør man for at informere hinandens medlemmer? Kan man benytte medlemsblade etc.?

Bønder og skovejere har brug for at fastholde et positivt omdømme via dialog og åbenhed overfor byboerne og de nye generationer, som ikke naturligt har forbindelse til land- og skovbrug. Jordejerne skal vise funktionen af landbrug og dermed legalisere landbrugets/skovbrugets behov.

Det er ønskeligt med øget information og kampagner til brugere og befolkning om korrekt adfærd.

Lad os få nogle fælles mål i de nordiske lande.

Spred kundskaber om Allemandsretten og friluftsorganisationer i Baltikum.

\section{Konklusioner}

- Kommunikation på alle niveauer skal sikre, at færdslen i naturen udvikles på en hensigtsmæssig måde uden store konflikter.

- Skab arenaer for dialog: Det er nødvendigt med nye fora, som faciliterer dialogen mellem forskellige brugere, for at undgå konflikter i en fremtid med større pres på arealerne. Ligeså er der behov for fora mellem organisationerne og NMR. 
- Dialog mellem enkeltpersoner ude i felten, mellem lokale grupper, mellem myndigheder og organisationer og mellem ejer- og friluftsorganisationer bør opprioriteres fremover.

- Vi anser det for at være en opgave for Nordisk Ministerråd at støtte og tilvejebringe platformen for en fortsat dialog mellem de forskellige parter, som har bidraget til nærværende projekt. Noget lignende konferencen i København skal være en tradition med opfølgning hvert år. Gør samarbejdsideerne konkrete og gør dem til praksis. Der er behov for at gøre politikerne ansvarlige.

- Vi anbefaler en hjemmeside, en internetbaseret portal for friluftsfolk, forskere og administration! Siden skal være en serviceside og en databank om friluftsmuligheder, rettigheder og ansvar i de forskellige nordiske lande. Siden skal også formidle forskningsresultater og udviklingsprojekter. 


\title{
9. Dannelse og uddannelse
}

\author{
- rettigheder og pligter
}

Vi har gode erfaringer med at samarbejde med landbruget. Der er en kropslig indgang til naturen - som også findes i friluftslivet.

Bo Skjöld, Friluftsfrämjandet, Sverige

Færre kender til livet på landet i dag. Urban livsstil gør, at folk ikke har tilstrækkeligt kendskab til naturen, og hvordan man færdes i den under hensyntagen til naturen, andre brugere og erhvervet.

Hvordan sikrer vi, at de kommende generationer får samme muligheder for at tage de unikke nordiske friluftstraditioner til sig? Hvordan sikrer vi et godt forhold mellem jordejere og befolkning baseret på et gensidigt kendskab til hinandens forudsætninger?

På møderne blev det pointeret, at der skal tilrettelægges og stimuleres til friluftsliv for børn og unge i skoleverdenen og i daginstitutioner, bl.a. via let adgang til naturen. Dette for at sikre de unikke nordiske grundprincipper og af hensyn til sundheden i den yngre generation.

Urbaniseringen har medfört att svenskar håller på att tappa den naturkunskap som
finns ”nedärvd” när man växer upp med naturen inpå husknuten, både vad som gäll-
er fauna och flora. Jag kan bara hålla med mötet om att detta faktum visar än större
på vikten av att sprida kunskap, framför allt till barnen, om dessa betingelser.

Kjell Bräster, Kennelklubben

\section{Ideer og eksempler}

\section{Finsk Håndbog}

For professionelle om allemandsretten og ansvar bliver publiceret i 2008.

\section{Allemandsretsdag, Finland}

Finland har en årlig allemansretsdag, hvor friluftslivet markeres.

\section{Direkte samarbejde mellem ejere og institutioner}

Der er mange eksempler fra alle landene på direkte samarbejde mellem skoler/børneinstitutioner og grundejere. Kan dette sættes i system og udvides? 


\section{Natursyn, Danmark}

I Danmark har vi en lang tradition for at diskutere natursyn. Måske fordi vi ikke har meget natur, der ikke er påvirket af menneskehånd. Denne diskussion finder vi vigtig og god.

Det danske naturvejledernetvcerk

Har en rig tradition for at formidle naturspørgsmål, natursyn, livet på landet, kultur og sundhed.

\section{Landbrugsorganisationer}

Benytter sig også af samfundskontakt og oplysningskampagner. Eksempel fra Norge:

I Den grønne skolen ønsker Norges Bondelag å gi barn og ungdom opplevelser, informasjon og kunnskap om landbruket i Norge. Materiell og aktiviteter er i første rekke laget for skole og barnehage. Du kan også møte Den grønne skolen på blant annet utdanningsmesser og Åpen gård.

www.bondelaget.no/skole/

\section{Vigtige iagttagelser og udsagn, som vandt generel tilslutning på den fælles konference.}

Den viden folk naturligt tilegnede sig før i tiden via direkte kontakt, bliver man nødt til at kompensere med bl.a. skoleundervisning. Husk, at børnene lærer bedst om naturen i naturen.

Organisationerne har et ansvar for, at deres medlemmer kender til korrekt opførsel og kender den frie færdsels (Allemandsretens) forudsætninger, f.eks. det personlige ansvar.

Dialogen skal styrkes i forhold til nye nordboere. Vi skal kende deres ønsker, og samtidig skal der gøres en indsats for at stimulere til friluftsliv og formidle grundprincipperne bag Allemandsretten og traditionel hensyntagen til denne gruppe.

Det er ønskeligt med forbedret oplysning til skolerne og børneinstitutionerne om deres muligheder for at færdes i naturen.

Der skal arbejdes på at finde frem til de gamle stier, de gamle ruter og den gode historie om fortiden.

Der skal gøres mere for at formidle alle friluftslivets gode virkninger.

\section{Konklussioner}

- Der skal stimuleres til friluftsliv for børn og unge i skoleverdenen og i daginstitutioner, bl.a. via let adgang til naturen. Først og fremmest for at sikre sundheden, naturglæden samt de unikke nordiske traditioner for udeliv. 
- Skoleværket bør pålægges et ansvar for, at viden om livet på landet samt kendskab til adgangsforhold og Allemandsrettens muligheder og forpligtelser integreres i undervisningen.

- Grundprincipperne i Allemandsretten skal endvidere spredes blandt nye nordboere.

- Fokus på udelivets positive effekter bør styrkes med en årlig fællesnordisk friluftsdag. 


\section{Forskning - Det nødvendige overblik over udviklingen}

Der er behov for forskningsprogrammer indenfor friluftsliv og helse. Det er nødvendigt at kortlægge og undersøge kommercialiseringen.

Det er særdeles aktuelt med forskning indenfor stress og grønne områder, og om hvordan urbaniseringen påvirker vores adfærd.

Der er behov for mere viden om befolkningens ønsker og ejernes holdninger. Dvs om friluftslivet og sameksistensen med de private jordejere.

Endelig ved vi for lidt om friluftslivets reele indvirkning og forstyrrelse.

Vi foreslår et projekt, som skaber et „overview“ over den forskning, der allerede er udført indenfor friluftsliv og rekreation. Gerne koblet til en webbaseret databank.

Spørgsmål fra møderne, som kan inspirere til forskning og reseach:

Vedrørende sammenlignende studier mellem landene:

- Hvor godt fungerer de rekreative muligheder nær byerne både på privat og offentligt land

- Hvordan samarbejder private jordejere med kommunerne i de nordiske lande

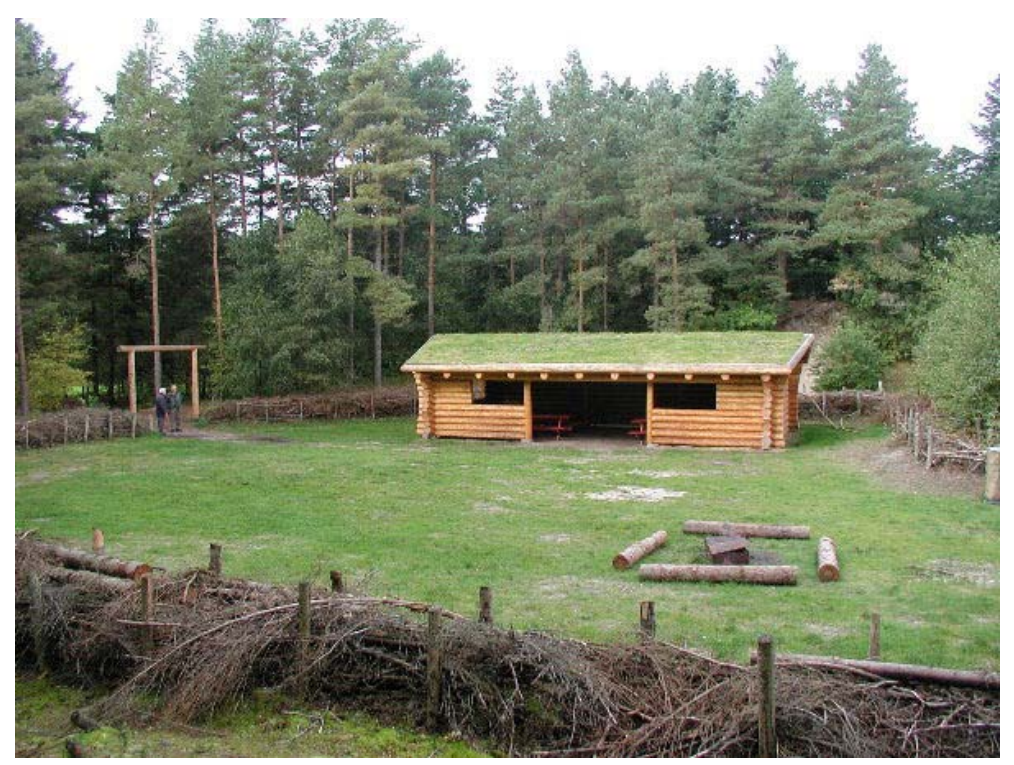


Vedrørende holdninger hos de forskellige grupper:

- Brugernes ønsker: Hvor vil de gerne være, hvad vil de gerne lave derude? Efterspørger friluftsbrugere flere faciliteter?

- Hvad er naturturisterne og befolkningens holdning til betaling?

- Kender folk deres rettigheder når de dyrker friluftsliv?

- Turisternes syn på, hvad værdierne ved naturoplevelserne er.

- Grundejernes holdning til friluftsliv på deres ejendom: Vil de tage penge for det, hvis du har muligheden?

- Den nye gruppe i befolkningen: Tilflyttere fra øst og syd og deres naturbrug.

- Hvilken type konflikter findes, hvor mange og hvor store er konflikterne?

Vedrørende kommercialisering:

- Analyse af, hvad det er man kapitaliserer: Adgang, oplevelser, formidling eller praktisk hjælp?

- Hvad er konsekvenserne af kommercialisering?

- Er penge den eneste måde at regulere forholdene, eller er der andre incitamenter hos lodsejerne for at involvere sig i friluftslivet?

- Model for hvordan indtægterne distribueres til de lokale

Vedrørende friluftsliv på privat ejendom generelt:

- Hvad er de virkelige trusler mod friluftsliv og friluftstradition?

- Hvornår giver øget publikumspres slid på naturen?

- Den nordiske friluftsånd: Hvordan adskiller vi os fra resten af Europa?

- Hvordan møder vi dagens børn og unge med attraktive friluftstilbud?

- Hvilke friluftsformer vil vokse fremover?

- Hvordan kommer klimaforandringerne til at påvirke friluftsliv og naturturisme. 


\title{
Konferenceindlæg 1
}

\section{Friluftsliv på privat jord - Forudsättningar og visioner i Norden}

\author{
Ulf Silvander, Generalsekreterare for Svenskt Friluftsliv
}

Hjärtligt välkomna allesammans till denna konferensen som är ett resultat av det nordiska projektet "samexistens mellan markägare och friluftsliv" eller på Dansk ”sameksistens mellem jordejere og friluftsliv".

Jag vill att vi här idag ska inspirera varandra inför de möjligheter som friluftslivet ger; att vi generöst delar med oss av erfarenheter, kunskap, idéer och frågor som vi har.

För mig är friluftsliv en betydelsefull pusselbit en övergripande politik för hållbar utveckling - långsiktigheten, att skydda och utveckla våra viktigaste resurser - människan och miljön.

Friluftsliv kan utgöra en motkraft i ett samhälle där fler och fler av medborgarna blir tidfattige och tingrike (Öjsten Dahle, Styreleder i FRIFO).

Jag skulle vilja börja med några nyckelfrågeställningar i denna framställning och som delvis speglar vad detta nordiska projekt handlar om.

Vi vet att friluftsliv är den vanligaste formen av fysisk aktivitet för oerhört många människor. Samtidigt vet vi att en allt större andel av vår befolkning idag bor i större tätorter och städer där det ibland är långt till grönområden. Vi vet också att många människor har problem med sin hälsa. Det handlar om psykiska problem, övervikt, förslitningsskador osv. Ett friluftsliv, som tidigare i hög grad var en självklar ingrediens i våra liv, eller som togs om hand fullt ut av frivilliga krafter, behöver mer stöd från stat och kommuner.

Friluftslivet har ett egenvärde, det vet vi alla som håller på med det. Jag ger mig inte ut och åker skridskor, cyklar, vandrar, klättrar, paddlar eller vad det nu må vara för friluftsaktivitet därför att det är bra för samhället eller för mig själv. Jag gör det därför att det är roligt - sedan får jag de andra effekterna på köpet. Svenskt Friluftsliv har trots detta tagit fram en del siffror. Siffror som förskräcker. Och ger hopp. En studie vid vi lät genomföra vid Lunds universitet, 2006 visar att om vi som rör oss skulle bli 10 \% fler, så skulle det svenska samhället spara 1,7 miljarder kronor i form av till exempel mindre diabetes, färre stressrelaterade depressioner och lägre produktionsbortfall. Totalt sett beräknas bristen på fysisk aktivitet bland svenska folket kosta runt 6 miljarder kronor - varje år. 
Svenskt Friluftsliv arbetar därför för att våra medlemsorganisationer skall ta en aktiv del i arbetet med Fysisk aktivitet på recept.

Svenskt Friluftslivs medlemsorganisationer aktiverar genom sina aktiviteter människor runt om i Sverige. Dessa aktiviteter har en omfattning som motsvarar sysselsättningen i ett av de största svenska företagen (räknat som antalet aktivitetstimmar).

Förra året genomförde det största undersökningsföretaget i Sverige (SIFO) en studie på uppdrag av Svenskt Friluftsliv. Denna studie visade på att Svenska folket var positiv eller mycket positiv till friluftsliv som begrepp. Samtidigt menar 87 \% att friluftslivet är bra för hälsan.

Närheten till naturen är särskilt viktig för våra barn. Själv gläds jag över att min sjuåring har sin skolgård precis i skogsbrynet - med tillgång till spännande gömställen, blomstersnår och skidspår. Det är en betydelsefull motvikt till de frestande datorerna, TV-apparaterna och gameboxspelen, där spänningen i livet förmedlas artificiellt - och till stillasittande barn.

Att bli vän med naturen som liten är viktigt, för att man senare i livet ska våga sig ut. För många barn, som inte attraheras av idrotten med dess tydliga tävlingsmoment, kan friluftsaktiviteter som scouting, fiske eller cykling vara vägen till både gemenskap och bättre hälsa.

Också för de äldre är närhet viktigt - liksom tillgänglighet i form av välpreparerade gångvägar. Andelen äldre i samhället växer - efter 2010 räknar vi med att hela befolkningsökningen i Sverige kommer att bestå av pensionärer. De tätortsnära naturområdena kommer inte minst att bidra till en bättre hälsa hos våra många äldre.

Den stora gruppen nordiska medborgare, födda utanför norden, eller som har föräldrar som är det, utgör idag en ansenlig del av vår befolkning. Man räknar med att det i Sverige finns närmare 2 miljoner invånare med icke-nordiskt ursprung (20 \% av befolkningen). Många av dessa har inget förhållningssätt till friluftsliv. I vissa länder är skogen något farligt. Det finns minor, rövare eller farliga djur - det är ingen plats man ger sig ut till frivilligt. Här har vi friluftsorganisationer en stor uppgift att förmedla den nordiska friluftstraditionen till våra nya nordbor. För många, som kommer till Norden, framstår den nordiska naturen som svårtillgänglig och obekant. Men tillgången till en rik natur är en viktig del av vår välfärd, och en viktig del av den nordiska kulturen. Att aktivt verka för att öppna upp friluftslivet för nya grupper, borde vara en självklarhet!

Vikten av samsyn och samarbete med kulturmiljövården är ett annat fenomen som idag är aktuellt. Det handlar om "ett landskap", där natur och kultur nästan alltid finns närvarande, dock i olika grad och på olika sätt.

Hur ställer vi oss egentligen till nya former för friluftsliv? Är alla nya friluftslivsaktiviteter lika välkomna till våra föreningar och omfattas dem av allemansrätten? Jag tror att det är en viktig överlevnadsstrategi för det ideella friluftslivets föreningar att vara öppen för nya aktiviteter, att ha en 
öppen attityd och bjuda in dessa nya aktiviteter i vår gemenskap (givetvis bör de uppfylla våra gemensamma grundläggande värderingar). Jag ser då kanske främst lajv- rörelsen (rollspel i skogen), geocasting (skattletning med GPS), kajting (segla efter drake med skidor, skridskor eller surfbräda) och många flera. Ökad vilja hos allmänheten / medborgarna till motoriserad färdsel - kanske till glädje och nytta för den enskilde men till problem för "jordejere” och övriga friluftslivsutövare.

Men kommer klimatförändringarna påverka friluftslivet mer än vi tidigare förstått? Dels direkt med förändrat klimat - varmare vintrar (mindre snö) och kanske mer nederbörd på somrarna. Det finns också en indirekt påverkan, dels i förändrade resemönster dels förändrade produktionsmönster på den areella ytan. Jag tänker då på ökad biologisk produktion (skog eller energiskog) men också nya produktionssätt i skogen (GROT) vilket gör marken mindre nöjbar som friluftsmark. Istället kommer kanske friluftslivet att utövas i reservat och tätortsnära skogar. Vi kan få ett landskap som är uppdelat i ett produktionslandskap och ett rekreationslandskap.

Sedan finns ett gränssnitt mot det kommersiella friluftslivet och markägare. Där vi kan ana en annan attityd än till det privata / ideella friluftslivet. Den gula stapelns storlek kan alltid diskuteras.

\section{Konflikter}

Även om vi idag har en allemansrätt i de flesta nordiska länder som fungerar och även om vi inte har några stora konflikter mellan markägare och friluftslivet så är det en utveckling på gång som kallar på dialog och nya initiativ.

Dels har vi en ny generation nordbor som inte känner till allemansrätten (både på bland ägarna och friluftslivet), dels har vi de nya nordborna som jag talade om tidigare, men även de besökare som vi har från övriga Europa och värden. Kommer fransmän och tyskar i samma utsträckning som tidigare åka till Spanien för semester när växthuseffekten kommer innebära avsevärt högre temperaturer? Kommer vi få en turistström mot norr istället? Hur påverkar detta allemansrätten? I stora delar av norden har vi gott om utrymme, men i vissa fall finns trängselproblematik och det är främst där som allemansrätten ifrågasätts. Kommer ett ökat intresse för nordlig semester att påverka fastighetsbildningen i norden. D.v.s. kommer en större andel av "jordägarna" ha ett icke nordiskt ursprung och hur agerar de (då dessa inte har en naturlig erfarenhet av allemansrätten). Vi ser redan idag att icke svenska skogsägare i Sverige bedriver ett annat skogsbruk än de som är bosatta inom landet eller på den egna fastigheten. Kommer bebyggningstrycket på sjönära fastigheter att öka till skada för friluftslivet?

Kommer friluftslivet att förändras pga. klimateffekterna? Ja självklart. Med kortare vintrar, högre medeltemperatur så kommer vinter friluftslivet att få försämrade förutsättningar. Kommer då sommar friluftslivet att få 
det bättre? Ja säsongen kommer att öka, men nederbörden kanske ökar, amplituderna i vädret kommer att öka vilket knappast gynnar friluftslivet. Friluftslivet i sig själv däremot är kanske den enda aktivitet som inte behöver förändras/anpassas för att minska klimateffekterna.

\section{Ligger Sverige före / er Sverige på forkant med udviklingen?}

Det är en svår fråga att besvara. På ett generellt plan (på en generell måde) vill jag svara nej. Men varje nordiskt land är föregångare på något område. Sverige har haft en strandskyddslagstiftning som är bra, men lokalt har många dispenser givits (och nu är den föremål för en förändring). Sverige kommer nu starkt när det gäller forskning om friluftsliv. Dels arbetar Svenskt Friluftsliv för att sjösätta en forskarskola i friluftsliv, dels har vi påverkat forskningspropositionen så att det startats ett forskningsprogram: "Friluftsliv i förändring"

Inom programmet kommer data kring friluftsliv samlas in med hjälp av en nationell och regional/lokal postenkät samt landskapsanalyser av en handfull fallstudieområden. Forskningen inom projektet syftar till att; 1) analysera deltagande, icke-deltagande och hinder inom olika friluftsaktiviteter, 2) förbättra friluftsstatistiken och metoder för att mäta friluftsliv, samt 3) beskriva och analysera fallstudieområden från det svenska friluftslandskapet.

I det Svenska samhället finns och har funnits en tendens att lita till myndigheter. När den första nationalparken inrättades i Sverige fanns ingen expertis på svenska myndigheter (ja det fanns knappt myndigheter). Sedan dess har myndighetssverige utvecklats på samma sätt som i övriga Norden, dvs. fler och fler myndigheter med expertkunskap samtidigt som besluten och viljan att lyssna på den expertkunskap som finns hos de ideella organisationerna ar minskat. Jag tror att detta är ett strategiskt viktigt område att återta för de ideella friluftsorganisationerna.

\section{Kan konferensen bidra?}

Kan då en konferens av detta slag / nordiskt projekt bidra med något $\mathrm{i}$ Sverige? Kan vi och våra beslutsfattare lära något av de erfarenheter som man har i övriga nordiska länder och vice versa?

På denna fråga kan jag definitivt svara JA. Och jag kan utveckla det något.

Jag menar att det nordiska samarbetet som vi inom friluftslivets paraplyorganisationer (Friluftsrådet, FRIFO, FL, Svenskt Friluftsliv och Friluftsforum) är mycket viktigt. Jag tror - nej jag vet, att det har inverkan på hur friluftslivet positionerar sig i de olika nordiska länderna.

Det är en fördel att kunna visa på en gemensam nordisk strategi i friluftsfrågorna. Friluftslivet är snart nog ett av de få unika nordiska som finns att samarbeta kring när allt fler frågor flyttar till Bryssel och EU. En gemensam friluftspolitik för Norden är ett mål som vi har diskuterat mellan de olika paraplyorganisationerna. 
Kunskapsmässigt ser det inte likadant ut i de olika (forskellige) nordiska länderna. Därför finns en stor potentiell vinst av att överföra kunskap mellan länderna. Vi kan lära av varandras misstag och framgångar.

Jag vill avslutningsvis lägga på denna bild som visar på Svenskt Friluftslivs ledord och som gäller allt friluftsliv.

- Friluftsliv skapar nytta:

- Våra ledord: Gemenskap, Hälsa, Lärande, Samhällsnytta, Glädje

Gemenskap

Friluftsliv sysslar man med tillsammans - hela familjen, över generationsgränserna. Det är också ett sätt att träffa nya människor och skapa relationer.

Hälsa

Man mår bra av friluftsliv. Det förebygger stress och utbrändhet, ger kondition och styrka. Och så sover man bättre. 87 procent av svenska folket uppger att friluftsliv är bra för hälsan*.

\section{Lärande}

Ny kunskap och nya insikter är utvecklande, inte minst för barn och ungdomar. När man håller på med friluftsliv skaffar man sig kunskaper som ger trygghet i naturen, man får också förståelse och känsla för vår natur och våra natur- och kulturvärden.

\section{Samhällsnytta}

Samhället mår bra av friluftsliv. Det bidrar till en bättre folkhälsa och skapar sysselsättning. Dessutom finns det forskning som visar att demokratin fungerar bättre när människor engagerar sig i föreningslivet. Svenskt Friluftslivs 21 medlemsorganisationer har tillsammans ca. 2 miljoner medlemmar och 10000 demokratiskt valda styrelser.

Glädje

Friluftsliv är nyttigt både för individen och för samhället. Och framför allt - det är roligt!

61 procent av svenska folket har en mycket positiv inställning till friluftsliv.

Tack 


\title{
Konferenceindlæg 2
}

\section{Sameksistens mellem jordejere og friluftsliv}

\author{
- Input fra de fem nordiske lande forår 2007
}

Ida Kryger, koordinator på projektet, ansat i Friluftsrådet

Kort om nærvœrende projekt:

Projektet har til formål at samle og dele erfaringer i Norden. Det er ønskeligt, at der udvikles nogle anbefalinger til beslutningstagerne samt en rapport med gode ideer, forslag og eksempler fra landene.

De mange input og ideer kan opdeles i følgende temaer

- Udvikling af byerne

- Udvikling i friluftsinteresserne

- Respekt for den private ejendomsret og erhvervet

- Naturturisme

- Kommercialisering

- De offentlige arealer

- Kommunernes rolle og ansvar

- Skoler og dannelse

- Dialog og viden

Friluftsliv på privat jord

Sameksistensen hviler på:

- Retten til fri færdsel (allemandsret)

- Frivillige aftaler

- Besøgsgårde, formidling, stier, gårdbutik etc

Hvordan går det så?

- Fornuftig adfærd hos gæsterne, problemerne er små og enkeltstående.

- Jordejerne accepterer gæsterne, de fleste endda med glæde.

- Aftaler mellem jordejerne og børnehaver, skoler, skiklubber og lignende falder som regel på plads.

- Nogen steder ser man endda eksempler på nye, fremadrettede initiativer.

- Fred og fordragelighed i hele Norden!

Sådan er det som oftest derude i praksis... 


\section{Er det så ikke godt nok?}

Mange føler, at det er tid til dialog og nye idéer. Deltagerne har udtrykt, at der kan gøres mere. Udviklingen kræver det.

Ideerne skal sprudle - der skal være dialogmøder på kryds og tværs parterne skal sammen afprøver nye muligheder - nordiske netværk skal udveksle og informere.

En tid med forandringer - Befolkningen flytter sig fysisk og mentalt

- fra land til by

- mod mindre forståelse for erhvervene

- mod mere tid og flere penge til friluftsliv

- mod nye friluftsformer som fylder i landskabet

- mod en øget naturturisme

- dermed bliver der mulighed for at kommercialisere friluftslivet

Kik engang på nogle udtalelser fra møderne til eftertanke og provokation...

Vi ved alt for lidt om hvad befolkningen egentligt ønsker

Vi er ikke særlige opfindsomme, der mangler i høj grad gode og anderledes projekter, der omhandler friluftsliv på privat jord

Planlægningen af byer og beboede områder tager for lidt hensyn til rekreative værdier. Økonomiske interesser råder

I f.eks Oslo er adgang til havet for de få

Allemandsretten skal være curriculum i skolerne

Hensynet til bybefolkningens mulighed for at komme ud i landskabet vægtes for lavt $\mathrm{i}$ alle de nordiske lande

Der bør være flere restriktioner og fredninger på baggrund af rekreative interesser

Hensynet til de bynære jordejere mangler i høj grad, når kommunerne planlægger

Kommercialiseringen sker alt for tilfældigt uden myndighedernes bevågenhed og indblanding, og uden overordnet planlægning.

Nogle grupper af friluftsfolk kommer til at vende sig til mere støj fra andre grupper af friluftsbrugere. Det gør jordejerne også...

Dialogen har ligget deltagerne på sinde i alle landene. Dialog mellem brugere og ejere på organisationsniveau er ikke godt nok. Medlemmerne skal lære hinanden at kende. Flere møder, forums og skriftlige meddelelser i hinandens blade.

Konklusion: Dialog er på dagsordenen 


\section{Konferenceindlæg 3}

\section{Avtaler og forpliktelser mellom eiere og brukere i friluftslivet}

Vidar Holthe, Norges Skogeierforbund

\section{Rettsgrunnlag:}

Lov om friluftslivet av 1957: Ferdselsrett, oppholdsrett og nyttesrett Standard for «Levende skog», skogsertifisering etter PEFC

«Skogeier skal innen rammene av rimelig næringsutnytting og privatlivets fred bidra til hensiktsmessige løsninger for anlegging av stier, skiløyper, rasteplasser og lignende og for uteområder for barnehager, skoler og skolefritidsordninger, og gi tillatelse til slike når det ikke er i strid med viktige næringsmessige eller økologiske hensyn.»

Natur- og eierforhold

Norge er ca 325000 km2. Heraf 2,8 \% dyrket mark, 23 \% produktiv skog og 54 \% høyfjell. 80 \% av skogen er privateid (gårdsskog), 120000 eiere med i snitt 45 ha. $40 \%$ av landet administreres av Statskog

\section{Ferdselsrett}

- Ikke skille mellom kommersiell og annen ferdsel.

- Ikke skille mellom organisert og uorganisert ferdsel.

- Spørsmål om skade på naturen og fortrengsel: «ikke volder nevneverdig skade eller ulempe, utilbørlig fortrengsel eller skade»

- Motorferdsel er ikke allemannsrett (Lov fra 1977)

- Fri ferdsel på vassdrag

\section{Aktiviteter også med avtale}

Mye av disse aktivitetene er direkte tillatt etter friluftsloven, avtalene er et supplement til lovteksten

- Turstier med klopper (broer), varding og kvisting

- Skiløyper A,B,C, konkurranse, lysløype

- Riding, hestesentra - «garasje»-hester

- Orienteringsløp (VDG-avtale)

- Padling - rafting

- Motorcross, Paint-ball

- Turist-aktivitet 
Avtaler

To parter; grunneier og tilrettelegger. Tilrettelegger er enten forening og lag eller kommunen. Brukerne er sjelden avtalepart.

Tilrettelegger har ansvar for rydding og opparbeiding, merking (etter norsk Standard), preparering, renovasjon (plukke søppel) samt varsling til brukerne (om grunneiers næring og aktivitet) og omlegging

Grunneiers ansvar: Forpliktelse, hensyntagen ved næring, varighet, tinglysning, heftelse og varsling av næringsvirksomhet. Samt rettslig ansvar ved ulykke (ikke amerikanske tilstander)

\section{Betaling}

Ikke betaling for adgang, eller fordi naturen er pen, men Kompensasjon for økonomisk tap og betaling for tilrettelegging eller for leie av areal.

Eksempler på konfliktsaker er f.eks. Nordkapp-platået, Preparerte hundesledeløyper i Trysil samt strandsoneproblematikk, avtand til hytter, bading, ferdsel.

Avtaler på nett:

- Se vår hjemmeside: www.skog.no

- Avtaleformularer: http://www.skog.no/html/Utmark/kontrakt.asp

- Du kan også finne informasjon på: www.dirnat.no under friluftsliv 


\section{Konferenceinlæg 4}

\section{At åbne sin ejendom for friluftslivet}

Gårdejer Søren Madsen

Projekt „Køng Sogns Natursti “

- Forening dannet på landbrugets eget initiativ

- Bestående af 16 lodsejere

- Projektet indeholder etablering og åbning af syv spor der tilsammen er ca. $64 \mathrm{~km}$.

- Planlægning, koordinering og etablering gennemført på 10 måneder

- Stierne blev officielt indviet i 21. maj 2005

- Stierne er Danmarks største „Spor i Landskabet“

Landbrugets erfaringer fra Svinø

- Positiv omtale - frem for konstant kritik

- Meget positiv respons fra lokalbefolkning

- Respekt for frivilligheden

- Større forståelse for den landbrugsmæssige drift (udbringning af gylle, støjende maskiner, lukning af spor ved afgræsning eller jagt)

- Afsmittende effekt blandt kollegaer

Landbrugets negative erfaringer fra Svinø

- Problemer med løse hunde

- Bortfjernelse af affald

- Pasning af stierne ligger i den travle tid

- Foreningsliv skal passes

Konklusion

- Tingene skal komme nedefra

- Sporene er frivillige - og forbliver frivillige

- Skrækken for udefrakommende indblanding sidder der stadig

- Bedre sammenhold blandt kollegaer

- Drivkraften opretholdes bl.a. af goodwill fra naboer, lokalbefolkning, myndigheder og medier 


\section{Konferenceindlæg 5 \\ Den fælles nordiske ånd}

Jan Eriksen, Friluftsrådets direktør

Hvad er den nordiske ånd? Hvad kendetegner vore lande og folk? Og har vi noget til fælles i dag? For at besvare den opgave tog Jan Eriksen deltagerne med på en lille tidsrejse, der både inddrog historien og geografien.

Jan Eriksen mente, at man nok skulle tilbage til vikingetiden for at finde oprindelsen til den fælles nordiske ånd. De nordiske vikinger var frygtet rundt om i norden, og de rejste langt både mod øst, mod syd og mod vest. De var berygtede, ifølge anekdoterne bl.a. fordi de ikke frygtede autoriteter og stod sammen.

De nordiske lande har haft visse geografiske fælles træk som følge af den prækambiske foldning (Danmark kom i læ af de norske fjelde), det tempererede / polare klima og som følge deraf en vegetation, der i den sydlige del af norden har fremmet agerbrug.

Nordisk Råd blev stiftet i 1952, og Nordisk Ministerråd fulgte i 1971. De nordiske lande har et fælles særkende i kraft af deres demokratiske styreformer og som regel pragmatiske tilgange til livet. Noget som præger befolkningerne dybt.

Den nordiske friluftstradition er meget gammel og en del af opvækstvilkårene, især i landene Norge, Sverige, Finland. De nordiske friluftsorganisationer er derimod ikke så gamle. Friluftsrådet er ældst, stiftet i 1942, FRIFO i Norge blev dannet i 1989.

I 1992, da Friluftsrådet fyldte 50, opfordrede Gunnar Zettersten, fra svenske Naturvårdsverket, Friluftsrådet til at stå i spidsen for et nordisk friluftsråd. En af rekommandationerne fra 50 års jubilæet blev en opfordring til at intensivere det nordiske arbejde.

I 1993 blev det første møde holdt i København. Og Norge fik sekretariatsposten for det nye netværk i de første år.

Igennem årene er det blevet til mange møder og flere fælles konferencer.

Først om Allemandsretten i 1995. Allemandsret - eller retten til fri færdsel, som vi i Danmark siger, er stedse aktuel. Dengang i 1995 kom vi med fælles deklarationer / rekommandationer, og det har vi tilstræbt at gøre lige siden. I 1997 holdt vi en fælles konference om børn og natur. I 2000 blev Svenskt Friluftsliv dannet, og stod for en konference om bæredygtigt friluftsliv i 2003. Bynært Friluftsliv var emnet i 2005, som blev holdt her i Danmark. 
Netværket er gennem årene blev udvidet og styrket. Finland har fået sit Friluftsforum og er godt på vej, og vi har også kontakter i Island.

Ledelsen af netværket går på skift, cirka hvert andet år, og der holdes normalt 2 møder om året. Men også indimellem møderne har vi glæde og styrke ved at bruge hinandens kompetencer og muligheder.

Det er således også tilfældet med det projekt, som vi er samlet om her i disse dage.

Fortsat god fornøjelse. 


\section{Konferenceindlæg 6 \\ Om stadsexpansion och friluftsliv i stadsranden}

Mattias Qviström, forsker ved SLU, Alnap

\section{Inledning}

Stadsranden har under senare år uppmärksammats som en resurs för det vardagliga friluftslivet (se Countryside agency \& Groundwork 2004). Bland annat bjuder stadsranden på tillfälliga platser, som kan nyttjas för friluftsliv och andra informella aktiviteter i väntan på stadens expansion (Qviström \& Saltzman 2006). Samtidigt kan detta område bli en flaskhals mellan stadens grönområden och landsbygdens allemansrättsliga mark och därmed ett hinder för stadsbornas rekreation. Om vi tillåter att stadsranden domineras av motorvägspassager och byggarbetsplatser så riskerar det att fungera som en barriär för ett vardagligt friluftsliv, alternativt som en barriär mellan ett urbant och ett ruralt friluftsliv.

Inom det tvärvetenskapliga forskningsprojektet Efemära landskap: studier av stadsrandens dynamik studeras stadsrandens tillfälliga landskap och, för att låna ett begrepp av en av forskningsgruppens medlemmar, de permanentade provisorium som förekommer i stadsranden (se Olshammar 2002). Projektet uppmärksammar den omständighet att åtskilliga planförslag och byggprojekt försenas, vilket skapar tillfälliga platser som ibland kan ligga i vänteläge i årtionden innan exploateringen slutligen realiseras eller läggs i malpåse för gott. Dessa mellanrum saknar en officiell markanvändning, men används i det vardagliga livet bland annat för olika former av lek eller rekreation (se Qviström \& Saltzman 2006). Forskningsprojektet, som finansieras av Formas, är ett samarbete mellan Område Landskapsarkitektur vid SLU Alnarp och Institutionen för Etnologi vid Göteborgs universitet. Projektets fältstudier bedrivs i Göteborgsområdet och i Sydvästra Skåne, och det är erfarenheterna från de senare som ligger till grund för denna artikel. Som ett komplement till dessa studier har under våren 2007 även ett Nordiskt projekt påbörjats, finansierat av Nordiska ministerrådet; Stad och Land - stadsranden som resurs för samhällsplaneringen. Resultaten från det senare projektet har ännu inte sammanställts, så följande inlägg bygger i första hand på fallstudier av Skånes tättbefolkade slättlandskap.

Inledningsvis diskuteras de krafter som formar dagens stadsrand, därefter nämns ett konkret problemområde vilket följs av en av de potentialer som stadsranden erbjuder för det vardagliga friluftslivet. Kanske kan 
följande text ge en inblick i dessa komplexa och konfliktfyllda landskap, och landskapets potential för en vardaglig rekreation.

\section{Om stadsexpansion och landsbygdens omvandling}

För att se de möjligheter och problem som stadsranden bjuder för friluftslivet krävs en förståelse av såväl stad som land som dynamiska företeelser. Svårigheten att betrakta dessa företeelser som dynamiska skall inte underskattas: våra synsätt på stad och land är djupt rotade, och präglas av ett stort antal förgivet taganden. Även inom forskningen finns det gott om schablonbilder av stad och land, eftersom en överväldigande majoritet av de som forskar om mötet mellan stad och land antingen är experter på urbana företeelser eller på jord- och skogsbruk.

I Dolores Haydens A field guide to sprawl (2004) ges en lättillgänglig skildring av de nya landskap som håller på att ta form till följd av det sena 1900-talets urbanisering. Hayden skildrar en uppsjö av mer eller mindre nya begrepp och fenomen med hjälp av förföriska flygbilder och en hel del humor - två värdefulla redskap för att kunna distansera sig och kategorisera en så komplex verklighet. Här presenteras företeelser som Privatopia, Mall glut och Boomburg intill mer välkända företeelser som Drive through, Noice wall, Edge nodes, Interstate [highway] och Tire dump. Men, trots mångfalden av företeelser och begrepp tycks det finnas två genomgående teman. För det första löper motorvägen som en livsnerv genom dessa landskap. Privatbilismen är inte helt oväntat jämngammal med att diskussionen om en urbaniserad landsbygd för första gången dök upp och idag är det svårt att överskatta vägens roll som landskapsomdanande fenomen: vägarna och annan infrastruktur innebär en ganska brutal och påtaglig urbanisering av städernas omland. Inom lantbruket har traktorn haft en motsvarande roll som omdanare av landskapet, så kanske är det på sin plats att mer generellt tala om mobilitetens centrala betydelse för landskapets omdaning under 1900-talet. Samtidigt finns det en annan urbanisering som ibland inte syns över huvud taget. Kulturgeografen Nils Lewan talade redan för 40 år sedan om den dolda urbaniseringen av landsbygden i Skåne, och kanske kan man säga att denna urbanisering är än mer dold idag. Företag och privatpersoner flyttar ut på landet, renoverar gamla bondgårdar eller torp i enlighet med deras ideal om hur landsbygden bör se ut, för att därefter pendla till staden eller leva på kunder från staden som kommer ut för att uppleva landsbygd. Drömmen om landet är en central drivkraft för denna utveckling (Qviström 2005b). Vi vill å ena sidan bo på landet med alla dess fördelar, å andra sidan ha staden inom ett ögonblicks avstånd. Detta leder oundvikligen till vad som brukar kallas för urban sprawl. En vilja att bevara och att återskapa det traditionella kombineras här med en vilja att utveckla staden, att ta marknadsandelar, att hänga med i utvecklingen eller att göra framsteg, vilket sammantaget skapar ett motsägelsefullt landskap värdigt det moderna samhällets komplexitet och dess paradoxer. 
Hayden (2004) anlägger ett urbant perspektiv då hon ignorerar de förändringar som skett med jord och skogsbruket. Jord- och skogsbrukets landskap har genomgått en dramatisk omvandling under de senaste 50 åren. Ny teknik, en stegrad internationalisering och urbanisering samt en ny jord- och skogsbrukspolitik är några av de faktorer som har omdanat landsbygden (se Stenseke 1997). Om vi vill förstå de landskap som finns utanför städerna och deras potential för friluftslivet måste vi även studera dessa omvandlingsprocesser - det behövs en symmetrisk analys av stad och land. Alltför ofta studeras endast stadens tillväxt eller jord och skogsbrukets historia, vilket har lett till en ganska bristfällig förståelse för hur stadsrandens landskap har förändrats.

\section{Kanalisering av friluftslivet}

Hur har då stadsrandens landskap förändrats de senaste decennierna? Det finns ingen möjlighet att ge en uttömmande bild av denna utveckling här - istället nöjer jag mig med att lyfta fram ett skäl till oro och ett skäl till förhoppning. I båda fallen är det analyser som innefattar en symmetrisk studie av stad och land, och som hade varit svåra att uppmärksamma utan en sådan symmetrisk analys. Vi börjar med de dåliga nyheterna, som bygger på en analys av landskapet utveckling under de senaste decennierna och dess möjliga konsekvenser för friluftslivet.

Tillgängligheten till de stadsnära landskapen förändras med tillkomsten av bland annat nya ringleder eller förbifartsleder. Det är inte avstånd i rum utan i tid som är avgörande för tillgängligheten, sägs det. Men de mentala avstånden mäts även i rum, till exempel av synintryck. Dessutom är tillgängligheten inte något generellt, utan individbaserat. Med andra ord: med nya vägar ökar tillgängligheten för bilägare att ta sig ut till rekreationsområden, samtidigt som den vardagliga tillgängligheten kan försämras för samma personer och framförallt för de som inte har tillgäng till bil. Ringleder och andra trafikanläggningar bidrar till att kanalisera friluftslivet till vissa stråk, det vill säga till gång- och cykelleder med planskilda korsningar.

En motsvarande kanalisering eller koncentrering av friluftslivet tvingas fram av jordbruslandskapets omvandlingar. En ständigt ökad åkerstorlek och allt färre småvägar innebär färre möjliga gångstråk. Jordbrukslandskapets traditionella inslag, de så kallade småbiotoperna, har minskat drastiskt under efterkrigstiden och efterlämnat sig ett storskaligt industriellt landskap som i begränsad omfattning erbjuder möjligheter för rekreation. Det finns en påfallande risk att denna koncentration ska leda till ett ökat slitage och ökade konflikter om de stråk som blir kvar - vilket kan leda till en ond cirkel. De stadsnära landskapens omdaning kan alltså på sikt vara ett hot mot allemansrätten, åtminstone på det sätt vi idag definierar allemansrätten. 


\section{Upptäckten av ett nytt landskap}

Samtidigt som de traditionella inslagen i jordbrukslandskapet har minskat så har dessa landskap berikats med nya inslag. Men med de glasögon som vanligen nyttjas då jordbrukslandskapet skildras så rensas dessa fenomen bort och betraktas antingen som "urbana inslag" eller som anomalier. Om vi överger en uppdelning mellan stad och land och studerar alla de märkliga fenomen som hamnar i kategorin "övrigt" framkommer platser med potential för framtida friluftsaktiviteter: övergivna militärområden, flygplatser, gamla industriområden som är under avveckling, grustag och stenbrott som väntar på nya användningar, och så vidare (se Qviström 2005a för en längre diskussion). De strukturomvandlingar som kännetecknar stadsranden öppnar möjligheter för nya grönområden (Qviström 2007, se illustration 1). Även om vissa av dessa områden så småningom kommer att nyttjas för andra ändamål så kan de under en övergångsfas betraktas som en resurs för friluftslivet, även om tillgängligheten till dessa platser (eller deras status som privat eller offentlig) kan vara oklar. Denna oklarhet kan samtidigt vara en del av spänningsmomentet, inte minst för ungdomar, och "stökigheten" är en del av dessa platsers estetik (se illustration 2). Med större städer och med städer som breder ut sig över landsbygden kan dessa platser även stå för ett mer "urbant” eller "ungdomligt" friluftsliv i mer rurala sammanhang, och därmed överbrygga en konstruerad gräns mellan stad och land även i detta sammanhang. Dessa områden möjliggör en vitalisering av friluftslivet, inte minst i stadsrandens landskap.

\section{Källor}

Countryside agency \& Groundwork. (2004). Unlocking the potential of the rural urban fringe. A consultation by the Countryside agency and Groundwork. Cheltenham, UK.

Hayden, Dolores. 2004. A field guide to sprawl. W W Norton \& Company. New York \& London.

Olshammar, Gabriella. 2002. Det permanentade provisoriet: ett återanvänt industriområde I väntan på rivning eller erkännande. Chalmers tekniska högskola. Göteborg.

Qviström, Mattias. 2005a. "In the shadow of the city: on landscape transformations and spatial planning at the inner urban fringe”, i: Landscape change: conference proceedings ECLAS 2005. Department

of landscape architecture, University of Ankara.

Qviström, Mattias. 2005b. ”Väntans landskap: om studier av stadsranden och dess morgondag”, Nordisk arkitekturforskning, nr 3, sid 96- 105.

Qviström, Mattias. 2007 (under utgivning). "Landscapes out of order: studying the inner urban fringe beyond the rural urban divide", Geografiska annaler ser B.

Qviström, Mattias, Saltzman, Katarina. 2006. "Exploring landscape dynamics at the edge of the city: spatial plans and everyday places at the inner urban fringe of Malmö, Sweden”, Landscape research, vol 31, sid 21 - 41.

Stenseke, Marie. 1997. Bonden och landskapet. Lund university press. Lund. 


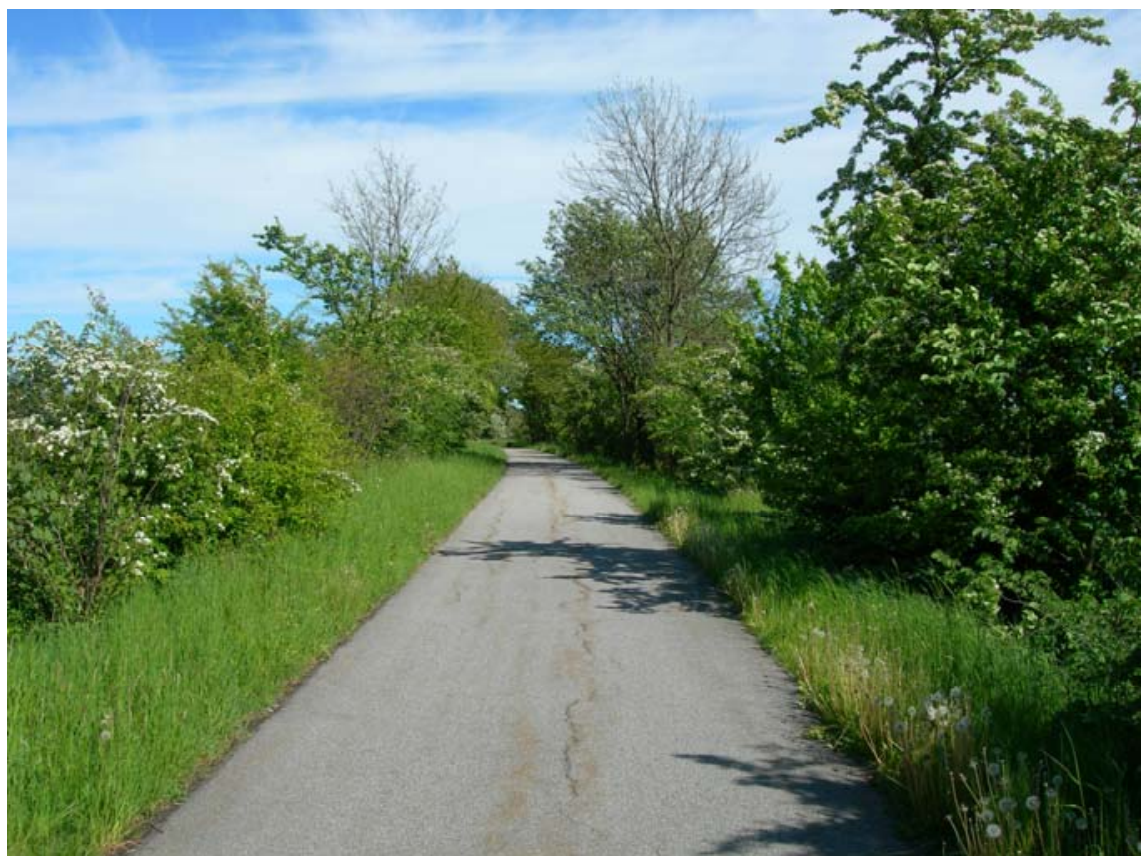

Illustration 1. En av de järnvägsvallar som har omvandlats till gång-och cykelstråk $i$ Malmös omland. Rekreationsintressena måste ta tillvara sådana restområden från tidigare aktiviteter för att kunna ha en chans i dessa konfliktfyllda landskap. Foto: Mattias Qviström.

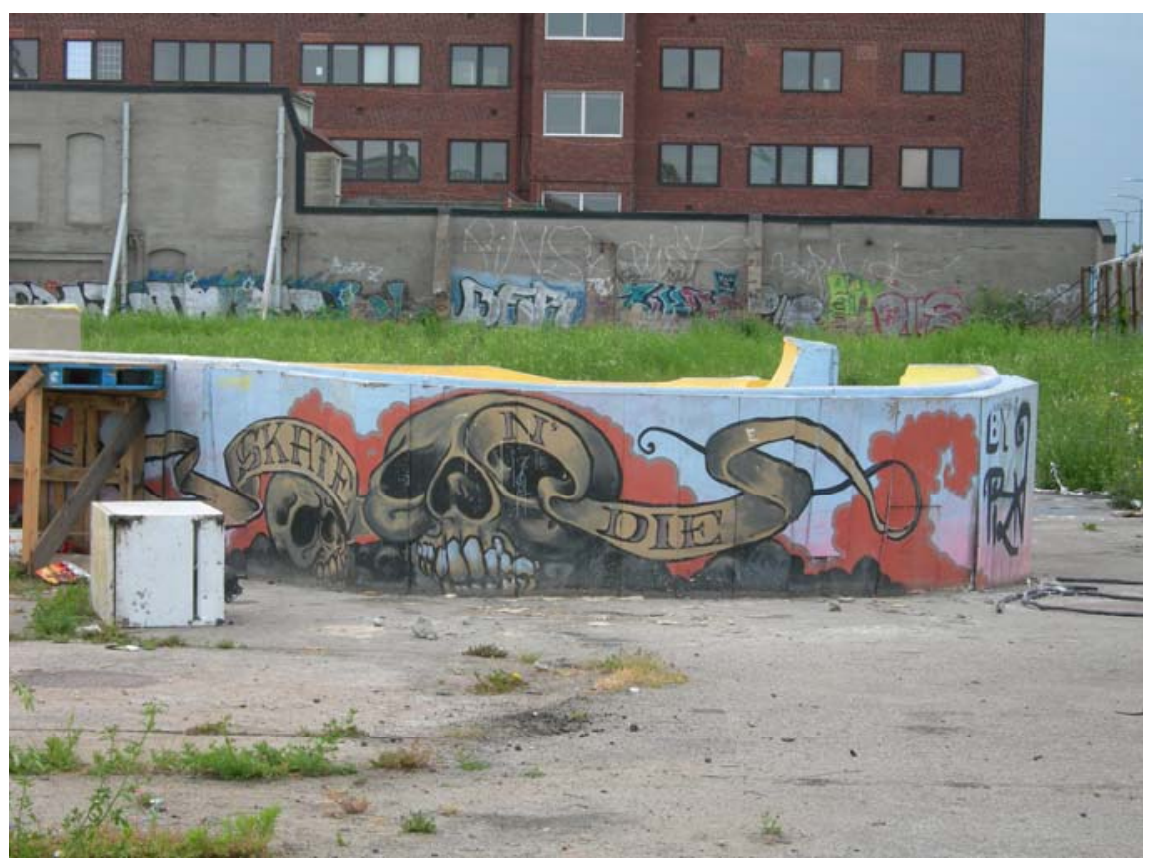

Illustration 2. Skateboard ramp på en av de tomter i Malmö som väntar på exploatering. Skateboard betraktas som en utpräglad urban företeelse, men ingenting hindrar att ramper av detta slag anläggs i mer rurala sammanhang (eller i en urbaniserad landsbygd) för att öppna upp för möten mellan rurala och urbana friluftsaktiviteter. Foto: Mattias Qviström. 


\section{Konferienceindlæg 7 Nature tourism}

\section{- a growing sector in rural development}

Liisa Tyrväinen, professor Finnish Forest Research Institute/(METLA)

University of Lapland

\section{Summary}

Today, large majority of Finns live in the southern parts of the country in urban development centres. According to Finnish national outdoor recreation survey, $40 \%$ of adult population take nature trips (LVVI 2000). However, due urbanization, increased leisure time and changes in lifestyles, $48 \%$ of Finns is interested in taking a nature trip travel within a year (Tyrväinen \& Silvennoinen 2001)

In many rural regions in Finland the key development areas are forestry and tourism. There are strong regional interests to create new employment opportunities in rural and peripheral areas. A programme launched by the Ministry of Environment for developing nature tourism and recreation aims at $100 \%$ increase in employment opportunities within the sectors by 2010 (30 key activities, 2004-2007).

Development possibilities and constraints are different in North-Finland compared to South-Finland. Tourism has been a key development area in Lapland from the beginning of 1980's. Substantial amount of tourism activities are located on state owned conservation and hiking areas around tourism centres. However, increasing amount of tourism activities including motorized use of nature has expanded tourism also into timber production forests. The strategic starting points of tourism development are (1) developing round-the-year tourism and (2) tourism centres generate employment opportunities also to surrounding rural areas.

In South-Finland the nature tourism development is characterized by a large number of private landowners (450 000 forest owners in whole Finland, aver. size $40 \mathrm{ha}$ ), forests are intensively used for timber production and small number and size of conservation areas. In South-Finland nature tourism business is relative small-scaled, mostly part-time enterprising combined with agriculture and forestry. The most common service is accommodation services (64\% of the entrepreneurs). Moreover, entrepreneurs are relatively aged, with rather little education in nature tourism (Tyrväinen 2002).

The quality of landscape and environment is one of the elements defining the quality of a nature tourism service. In Finland, forestry as a 
large industry has significant impact on the quality of landscapes for nature tourism. Therefore, synergies and conflicts between forestry and tourism need to be studied comprehensively. Tourists' and recreationists' attitudes are typically negative towards final harvesting, in particular towards clear cuttings, which is a widely use method in commercial forests. There are significant differences, however, within the clientele regarding environmental preferences and what kind of environments are preferred for different nature tourism activities.

The impact of nature tourism on local economies are difficult to assess, because impacts are distributed among many branches of business (travel, accomodation, rental and other services). It is estimetd that nature tourism counts for 20000 person-workyears in the whole country in 2002 (Koivula \& Saastamoinen 2005). In 2003, the tourism represented 2.4 percent of the Finnish GDP.(Min. of Trade \& Industry). In general, the statistical basis for evaluation inadeqaute,because data of small entreprises have not been collected. Finnish Tourist Board estimated that added value from nature tourism (2002) was 562 mill. euros: This equals approx. 1/5 of the added value of forestry in Finland.

In areas where growth of tourism has been fastest, in northern and northeastern Finland (Lapland, Kuusamo ja Kainuu) the economic importance is also larger. In Lapland the annual turnover of tourism is 400 mill. euroa (2000-2004), which is $4 / 5$ of total value of forest cluster (including e.g. paper and pulp industry)

It is estimated that tourism provides direct employment for 3000 4000 persons in Lapland (Saarinen 2004). Tourism helps the remote districts to stay populated by increasing economic growth and reflects in other entrepreneurship, for instance, in the construction sector.

In Finland as in other Nordic countries, customers have rather wide opportunities to use water and land areas based on common right of access. This is an important option for many entrepreneurs because their own land areas are often inadequate for running tourism business. Every fourth entrepreneur in South-Finland is using private or state owned lands in tourism business (Tyrväinen 2002). However, less than half of the entrepreneurs are willing to pay from the use of lands. Although routes and other constructions for recreational uses can be found in many places, today commercial services available for nature tourists are relatively limited. In the future, more attention should be made to produce different services for different type of clients.

Role of private landowners is important in developing tourism in Finland In a study by Tyrväinen et al (2002) the attitudes of private landowners towards the increased use of forests and other land areas for tourism and the willingness of landowners for various forms of co-operations with entrepreneurs were investigated. 
The results show that the common right of access to use private lands for recreation had caused relatively little problems for the landowners so far. Three quarters of landowners reported no nature tourism activities close to their lands. Only fifth of the landowners reported to have had any problems related to the use of their lands. Mainly the problems were caused by the use of private roads.

The attitudes of private landowners towards a new nature tourism entreprise close to their forest holding was fairly positive. More than third of the landowner had a positive attitude (43\% neutral) and less than one fifth a negative attitude towards the new entreprise. However, most landowners would prefer small-scaled firm with a local entrepreneur. Also the origin of the clients had an effect to the attitudes: an entreprise serving mainly foreign clients seemed to raise concerns. However, in general the effects of nature tourism were seen mainly as positive for the local community. The benefits included for example increased attractivity of the region and help in securing the supply of services in the rural areas. Tourism and traditional agriculture were seen produce equal amount of benefits for the rural society. The main threats related to tourism development were noise and litter problems as well as injuries caused to growing timber in the intensively used forest areas.

The landowners were also asked for what type of tourism activities their forest holding could be used for monetary compensation. The landowners were most willing to allow cross-country skiing routes to be constructed (39\% of the landowners). One fifth of the landowners would allow construction of hiking routes and some light facilities, such as birdwatch towers, for outdoor recreation. However, rather large part of repondents were not able to state their opinion yet. Only one tenth of landowners would directly accept mountain-bike, snowmobile and riding routes on their land. Almost half of the respondents stated that they would not allow this type of activities in their land property.

The landowners willingness to voluntarily increase the attractivity of the forests for nature tourism depended of the type of activity. The landowners were most willing to take care of the visual attractivity of their forest as well as to manage cultural biotopes such as meadows and pastures. Moreover, additional thinnings and early stage of managing saplings stands were relatively well accepted management measure; almost one fith of the owners were willing to do it voluntarily and close to $60 \%$ would be ready to consider it. However, only a few percent of landowners were willing to postpone regeneration of forests for promoting nature tourism in the area. However, monetary compensation was seen an important factor to get more support for landscape management measures: $42 \%$ of respondents stated to be ready for promoting these type of management activities if they would receive full compensation of the economic loss. 
The key challenges for the future are how forestry and tourism development should be combined and what type of adaptations are needed in traditional forest management practises in tourism development areas. New approaches include applying large-scale landscape planning in routine forest management planning and use of virtual landscape simulators in illustrating scenic impacts of forests management practises to various stakeholders within the participatory planning processes. Moreover, conditions and rights for using nature based on 'everyman's right' for recreation and for business purposes should be clarified. In addition, new types of agreements and markets are needed between tourism entrepreneurs and private landowners to promote nature tourism development and to achieve mutual benefits at local level.

Moreover, the new conservation areas should be allocated to areas where they support recreational and tourism development. Also a more flexible system of subsidies for private forest owners should be developed; the financial support should cover also landscape management measures needed in tourism development areas.

In the future more comprehensive information e.g. on social and economic impact of nature tourism needed for decision-making. Research related to nature tourism has been conducted in Finland since 1990s, but is has been fragmented and coordination needed at national level.

In the future the main information needs are e.g.

i. impacts of tourism on health and well-being,

ii. social and economic impacts of nature tourism on regional and local economies,

iii. development needs for nature tourism entrepreneurship.

A new research programme "Well-being from the Forests" is being prepeared at the FFRI, which will begin in 2008. Main challenges for future research are firstly, to get more knowledge about international tourists' environmental expectations, secondly, to study the regional income and employment effects caused by tourism, and thirdly, to create processes on how the different land-use interests are reconciled in decisionmaking. 


\section{Bilag 1 \\ Deltagerlister}

Tilmeldte ved fokusgruppemødet i København den 8. januar 2007

Ole Hjort Caspersen, Det Biovidenskabelige Fakultet, Københavns Univeristet

Tanja Olsen, Dansk Skovforening

Marie-Louise Bretner, Dansk Skovforening

Philip Hansen, Landbrugsrådet

Godsejer Johan Scheel, Ryegaard

Godsejer Eirik Vinsand, Asnæsgård

Finn Watson, Danmarks Jægerforbund

Nich Leyssac, Danmarks Naturfredningsforening

Thomas Johansen, Danmarks Naturfredningsforening

Bo Fisker, DGI

Kirsten Bjørnbak Nielsen, Friluftsrådet

Ida Sloth Bonnevie, Friluftsrådet

Ida Kryger, Friluftsrådet

Pernille Vesterløkke, Skov- og Naturstyrelsen

Tilmeldte ved fokusgruppemødet i Stockholm den 7. marts 2007-11-12

Generalsekreterare Bo Skjöld, Friluftsfrämjandet

Forsker Mattias Qvisttröm, Sveriges Lantbruksuniversitet,

Jordbrukspolitik/markägarfrågor Eilert Apelqvist, Lantbrukarnas Riksförb, LRF

Handläggare Jesper Taube, Naturvardsverket

Skogsskötselspecialíst Dan Rydberg, Skogsstyrelsen

Forsker Cecilia Rätz, SLU, Uppsala

Medlem Kjell Braster, Kennelklubben

Informationschef Pelle Andersson, Svenska Turistföreningen

Generalsekreterare Ulf Silvander, Svenskt Friluftsliv

Projektleder Ida Kryger, Friluftsrådet, Danmark

Tilmeldte ved fokusgruppemødet i Oslo den 7. marts 2007

Harald Tronvik, Frifo

Morten Dåsnes, Friluftsrådenes landsforbund

Anne Mari Aamelfot Hjelle, Den Norske turistforeningen

Asbjørn Olsen, Oslo og omland friluftsråd

Margrete Skår, Norsk Institutt for naturforskning (NINA)

Cecilia Albakken, Bondelaget

Synnöve Hognestad, Fylkesmannen i Rogaland

Arild Sørensen, Direktoratet for naturforvaltning, Trondheim.

Bjørn Helge Bjørnstad, Skogbrukets Kursinstitutt

Vidar Holthe, Norges Skogeierforbund

Gaute Nokleholm, Norskog

Ida Kryger, Friluftsrådet 
Tilmeldte ved fokusgruppemødet i Reykjavik den 24. april 2007

Sigurgeir porgeirsson, Bændasamtok Island (landbrugsorg.)

Eiríkur Blöndal, Búnaðarsamband Vesturlands (landbrugsorg.)

Bergur Sigurðsson, Landvernd (natur og Friluftsliv)

Brynjólfur Jónsson, Skogræktar felag Island (Skovorg.)

Páll Guðmundsson, Ferdafelag Island (Friluftsorg)

Forsker Auður Sveinsdóttir, Landbúnaðarháskóli Íslands

Forsker Bjarni E. Guðleifsson, Landbúnaðarháskóli Íslands

Unnur Björg Hansdóttir, Landbunadarraduneyti (Landbrugsdepartementet)

Trausti Baldurson fra Miljöstyrelsen

Umhverfisstofnun (Myndighed)

Gunnar Einarsson, SSH (Myndighed/Kommune)

Ida Kryger, Friluftsrådet Danmark

Tilmeldte ved fokusgruppemødet i Helsinki den 24. maj 2007

Jurist Helena Ålgars, SLC (landbrugsorg.)

Informatör Bettina Selander, SLC (landbrugsorg.)

Reporter Michael Godtfredsen, SLC (landbrugsorg.)

Lea Jylha, MTK (Skovorg.)

Secretary General Fred Sundvall, The Equestrian Federation of Finland (friluftsorg.)

Head of department Matti Hirvonen, Suomen Latu - Central Association for Recreational Sports and Outdoor Activities (friluftsorg.)

Managing Director Hannu Laine, Finnish Boating Association (friluftsorg.)

Nature Conserv. Officer Tapani Veistola, The Finnish Association for Nature Conservation (friluftsorg.)

Resecher Maija Sipilä, Finnish Forest Research Institute.

Project manager Ida Kryger, The Danish Outdoor Council 
Deltagerliste ved Den nordiske konference: Sameksistens mellem jordejere og friluftsliv den 13. og 14. juni 2007

\begin{tabular}{|c|c|c|c|}
\hline Navn & Titel & Organisation & Land \\
\hline Liisa Tyrväinen & Professor & Finnish Forest Research Institute & Finland \\
\hline Jacob P. Joensen & Medarbjder & HFS & Færøerne \\
\hline Harald Tronvik & Generalsekretær & FRIFO & Norge \\
\hline Odd Inge Vistad & Seniorforsker & $\begin{array}{l}\text { NINA, Norsk Institutt for Natur- } \\
\text { forskning }\end{array}$ & Norge \\
\hline Arild Sørensen & Rådgiver & Direktoratet for Naturforvaltn. & Norge \\
\hline Asbjørn Olsen & Medarbejder & Oslo og Omland Friluftsråd & Norge \\
\hline Vidar Holthe & Konsulent & Norges Skogeierforbund & Norge \\
\hline Jesper Taube & Direktör & Naturvårdsverket & Sverige \\
\hline Göran Andersson & Medarbejder & Friluftsfrämjandet & Sverige \\
\hline Eilert Apelqvist & Konsulent & LRF og Svenska Friluftsrådet & Sverige \\
\hline Mattias Qvistrom & Professor & SLU & Sverige \\
\hline Ulf Silvander & Generalsekretær & Svenskt Friluftsliv & Sverige \\
\hline Philip Hansen & Samfundskontaktchef & Landbrugsraadet & Danmark \\
\hline Jesper O. Lehmann & Projektkoordinator & Landbrugsraadet & Danmark \\
\hline Anton S. Olafsson & Frivillig & Landskabsværkstedet & Danmark \\
\hline Tanja B. Olsen & Forstfuldmægtig & Dansk Skovforening & Danmark \\
\hline Nicolas Leyssac & Naturpolitisk medarbejder & Danmarks Naturfredningsforening & Danmark \\
\hline Ole Hjorth Caspersen & Senior Rådgiver & $\begin{array}{l}\text { Center for skov, landskab og } \\
\text { planlægning, KU }\end{array}$ & Danmark \\
\hline Dorthe O. Andersen & Frivillig & Danmarks Idræts-Forbund & Danmark \\
\hline Søren Præstholm & Konsulent & $\begin{array}{l}\text { Danske Gymnastik- og Idrætsfor- } \\
\text { eninger }\end{array}$ & Danmark \\
\hline Johan Scheel & Godsejer & Asnæsgård & Danmark \\
\hline Kirsten Nielsen & Næstformand & Friluftsrådet & Danmark \\
\hline Jan Eriksen & Direktør & Friluftsrådet & Danmark \\
\hline Ida Sloth Bonnevie & Informationsmedarb. & Friluftsrådet & Danmark \\
\hline Ida Kryger & Konsulent & Friluftsrådet & Danmark \\
\hline Hans Skotte Møller & Sekretær for NFK-gruppen & Nordisk Ministerråd & Danmark \\
\hline Søren Madsen & Jordejer & & Danmark \\
\hline
\end{tabular}




\section{Bilag 2}

Den nordiske konference

Sameksistens mellem jordejere og friluftsliv

13. - 14. juni 2007, København

PROGRAM 13. juni

$13.00 \quad$ Frokost

14:00 Velkomst

14:10 Introduktion: Friluftsliv på privat jord. Forudsætninger og visioner i Norden Ulf Silvander, Generalsekreterare for Svenskt Friluftsliv, S

Byudvikling, nye friluftsformer, ændret økonomi, øget friluftsturisme og naturligvis den nordisk tradition er virkeligheden i Norden år 2007

14:30 Visioner og input fra fem nordiske møder foråret 2007

Ida Kryger, Projektleder i Friluftsrådet, DK

Konferencen bygger ovenpå ideer og input fra møder i de 5 nordiske lande. Pointer, highlights og visioner fra disse møder skitseres og perspektiveres.

14:50 Avtaler og forpliktelser mellom eiere og brukere i friluftslivet Vidar Holthe, Norges Skogeierforbund, N

I Norge har man en lang tradition for friluftsliv på privat jord. Vidar Holthe fra Skogeierne giver et indblik i det mangfoldige net der sikrer samspillet: Aftalepairer, samtaler, uskrevne og skrevne regler samt det nyeste eksempel på samarbejde mellem ejerorganisationer og turistforeningen

15:10 At åbne sin ejendom for friluftslivet Søren Madsen, jordejer, DK

Søren Madsen har sammen med andre lodsejere tilrettelagt et "Spor i Landskabet" og åbnet op for friluftsliv på sin ejendom.

15:30 kaffepause

16:00 Den nordiske ,friluftsånd“ Jan Eriksen, Direktør i Friluftsrådet, DK

I Norden har vi et unikt og traditionsrigt syn på naturen og brugen af den. Hvilken værdi har det nordiske natursyn for os i dag?

16:30 Workshops

Indenfor temaerne: Den aktuelle udvikling, Dannelse og ansvar, Retten til at færdes frit i naturen samt Dialog og netværk.

18:00 Afrunding på workshops

19:15 Socialt arrangement med spisning

Ca 21:30 Dagens program slutter 
PROGRAM 14. juni

8:30 Om stadsexpansion och friluftsliv i stadsranden

Mattias Qviström, forsker ved SLU, Alnap, S

Städerne har genemgået en omdanning gennem de senste 50 år. Det kalder på nytænkning og kreativitet $i$ de bynære land- og skovområder. Zonen mellem by og land byder på hidtil uudnyttede muligheder för jordbrukare såväl som för friluftslivet. Föreläsningen syftar till att ge insikter i de senaste årens landskapsforskning om det stadsnära landskapet.

8:50 Naturturisme, en voksende faktor

Liisa Tyrväinen, Finnish Forest Research Institute, FI

Interessen og mulighederne for at bruge fritiden i naturen er stigende $i$ befolkningen. Dermed bliver udfordringerne men også mulighederne for bosatte i landområderne større. Oplægsholderen tager udgangspunkt i udviklingen hos den laplandske befolkning.

9:15 Workshops

Indenfor temaerne: Urbanisering, Friluftsturisme og kommercialisering, Lovgivningen og de lokale myndigheders rolle samt Forskningsprojekter

11:00 En friluftsoplevelse i Københavns havn

13:00 Frokost i Friluftsrådet

$14: 15$

Anbefalingerne videregives. Ministerrådet sammenfatter og perspektiverer Hans Skotte Møller, Nordisk Ministerråd, DK

14:30 Afrunding og tak for denne gang 